\title{
Effect of ceramic membrane channel diameter on limiting retentate protein concentration during skim milk microfiltration ${ }^{1}$
}

\author{
Michael C. Adams and David M. Barbano ${ }^{2}$ \\ Northeast Dairy Foods Research Center, Department of Food Science, Cornell University, Ithaca, NY 14853
}

\begin{abstract}
Our objective was to determine the effect of retentate flow channel diameter (4 or $6 \mathrm{~mm}$ ) of nongraded permeability $100-\mathrm{nm}$ pore size ceramic membranes operated in nonuniform transmembrane pressure mode on the limiting retentate protein concentration (LRPC) while microfiltering (MF) skim milk at a temperature of $50^{\circ} \mathrm{C}$, a flux of $55 \mathrm{~kg} \cdot \mathrm{m}^{-2} \cdot \mathrm{h}^{-1}$, and an average cross-flow velocity of $7 \mathrm{~m} \cdot \mathrm{s}^{-1}$. At the above conditions, the retentate true protein concentration was incrementally increased from 7 to $11.5 \%$. When temperature, flux, and average cross-flow velocity were controlled, ceramic membrane retentate flow channel diameter did not affect the LRPC. This indicates that LRPC is not a function of the Reynolds number. Computational fluid dynamics data, which indicated that both membranes had similar radial velocity profiles within their retentate flow channels, supported this finding. Membranes with $6-\mathrm{mm}$ flow channels can be operated at a lower pressure decrease from membrane inlet to membrane outlet $(\Delta \mathrm{P})$ or at a higher cross-flow velocity, depending on which is controlled, than membranes with $4-\mathrm{mm}$ flow channels. This implies that $6-\mathrm{mm}$ membranes could achieve a higher LRPC than 4-mm membranes at the same $\Delta \mathrm{P}$ due to an increase in cross-flow velocity. In theory, the higher LRPC of the 6-mm membranes could facilitate $95 \%$ serum protein removal in $2 \mathrm{MF}$ stages with diafiltration between stages if no serum protein were rejected by the membrane. At the same flux, retentate protein concentration, and average cross-flow velocity, 4 -mm membranes require $21 \%$ more energy to remove a given amount of permeate than 6-mm membranes, despite the lower surface area of the 6-mm membranes. Equations to predict skim milk MF retentate viscosity as a function of protein concentration and temperature
\end{abstract}

\footnotetext{
Received June 1, 2015.

Accepted September 1, 2015.

${ }^{1}$ Use of names, names of ingredients, and identification of specific models of equipment is for scientific clarity and does not constitute any endorsement of product by authors, Cornell University or the Northeast Dairy Foods Research Center.

${ }^{2}$ Corresponding author: dmb37@cornell.edu
}

are provided. Retentate viscosity, retentate recirculation pump frequency required to maintain a given cross-flow velocity at a given retentate viscosity, and retentate protein determination by mid-infrared spectrophotometry were all useful tools for monitoring the retentate protein concentration to ensure a sustainable MF process. Using 6-mm membranes instead of 4-mm membranes would be advantageous for processors who wish to reduce energy costs or maximize the protein concentration of a MF retentate.

Key words: microfiltration, protein, channel diameter, ceramic membranes

\section{INTRODUCTION}

Microfiltration (MF) has been used to separate serum proteins (SP) from casein micelles in skim milk (Samuelsson et al., 1997; Gesan-Guiziou et al., 1999; Solanki and Rizvi, 2001) and milk protein concentrate (Hurt et al., 2015). Membrane fouling, or buildup of soil on the membrane surface, limits MF flux. Membrane fouling is promoted by concentration polarization or accumulation of retained milk components near the surface of the membrane. Concentration polarization is enhanced by increased convection toward the membrane surface (i.e., higher flux) and increased concentrations of retained milk components (i.e., higher protein concentrations in the retentate). Concentration polarization is mitigated by increased back-diffusion from the membrane surface into the bulk flow (i.e., higher turbulence; Belfort et al., 1994). The Reynolds (Re) number (Equation [1]) is a dimensionless quantity that describes the degree of turbulence in terms of the ratio of inertial forces to viscous forces in a fluid:

$$
\operatorname{Re}=\frac{\rho \times D_{h} \times V}{\mu} ;
$$

Re increases with increasing fluid density $(\rho)$, hydraulic diameter of the flow channel $\left(\mathrm{D}_{\mathrm{h}}\right)$, and average cross-flow velocity of the fluid $(\mathrm{V})$, and decreases with increasing fluid viscosity $(\mu)$. Turbulent flow occurs at high Re $(>4,000)$ and is characterized by unstable mixing of 
the fluid within the flow channel. Samuelsson et al. (1997) found that the limiting flux (LF) of a skim milk MF process was directly proportional to the Re in the retentate flow channels of a tubular ceramic membrane. However, Samuelsson et al. (1997) only studied flow conditions within a single membrane, so $\mathrm{D}_{\mathrm{h}}$ was constant. Other studies that have microfiltered skim milk (Gesan-Guiziou et al., 1999) and milk protein concentrate (Hurt et al., 2015) using ceramic membranes with different retentate flow channel diameters determined that properties such as shear at the wall, average crossflow velocity, and retentate viscosity predicted the LF well, but Re did not.

Although there has been considerable focus on determination of the LF in MF processing (Samuelsson et al., 1997; Gesan-Guiziou et al., 1999; Hurt et al., 2015), little has been done to determine the maximum protein concentration attainable before a ceramic MF membrane begins to foul rapidly. This value could be called a limiting retentate protein concentration (LRPC). Identifying the LRPC would allow processors to produce liquid MF retentates with high protein concentrations. Higher LRPC would allow for lower volumes of liquid MF retentates to be used when fortifying formulations to a given protein target. The use of highly concentrated retentates would reduce the need for evaporation or drying of retentates to prevent diluting other ingredients by the water portion of the retentates. Knowing the LRPC could also help maximize SP removal. Increasing the retentate protein concentration in a continuous feed-and-bleed MF process would require a processor to increase the concentration factor $(\mathbf{C F})$. Higher $\mathrm{CF}$ increase the ratio of permeateto-retentate produced and would increase the amount of SP removed from the milk in an MF stage (Hurt and Barbano, 2010). The LRPC would be reduced by increasing the flux or the retentate viscosity and increased by increasing the average cross-flow velocity (Hurt et al., 2015).

Because tubular ceramic MF membranes can be operated under more turbulent conditions than polymeric MF membranes, SP passage and flux are higher for ceramic membranes (Zulewska et al., 2009). The enhanced SP transmission of ceramic membranes is advantageous because it reduces the amount of permeate produced for a given SP removal target by reducing the amount of diafiltration required (Hurt and Barbano, 2010). The benefits of ceramic membranes come at the expense of higher capital and energy costs. Ceramic membranes are more expensive than polymeric membranes per unit membrane surface area (Cheryan, 1998), and the energy required to maintain the high retentate crossflow velocities of tubular ceramic systems can be up to $10 \times$ that of polymeric spiral-wound membrane systems
(Cheryan, 1998). Finding ways to reduce the energy expenses of ceramic systems and developing applications for high-purity protein products produced with ceramic systems could promote growth of the ceramic membrane market. Maximizing the LRPC in ceramic membranes could confer a competitive advantage over polymeric membranes when MF retentates with high protein concentrations are desired. It remains unclear whether the enhanced turbulence caused by using tubular ceramic membranes with larger channel diameters would increase the LRPC relative to that achieved by ceramic membranes with smaller channel diameters.

Our objective was to determine the effect of ceramic membrane channel diameter (4 or $6 \mathrm{~mm}$ ) of nongraded permeability (Zulewska et al., 2009) 100-nm pore size membranes operated under nonuniform transmembrane pressure conditions (Hurt et al., 2010) on the LRPC while microfiltering skim milk at a temperature of $50^{\circ} \mathrm{C}$, a flux of $55 \mathrm{~kg} \cdot \mathrm{m}^{-2} \cdot \mathrm{h}^{-1}$, and an average crossflow velocity of $7 \mathrm{~m} \cdot \mathrm{s}^{-1}$.

\section{MATERIALS AND METHODS}

\section{Experimental Design}

A completely randomized split block design was used, in which membrane channel diameter was the whole-plot factor, retentate protein concentration was the subplot factor, and replicate was the blocking factor. The experiment was replicated 3 times in different weeks with 3 different batches of pasteurized skim milk. Each replicate took place over $3 \mathrm{~d}$ in a week. On the first day, raw skim milk $(750 \mathrm{~kg})$ was procured from the Cornell University Dairy Plant and pasteurized using a plate heat exchanger equipped with 3 sections: regeneration, heating, and cooling (model 080-S, AGC Engineering, Manassas, VA). Pasteurization temperature and holding time were $72^{\circ} \mathrm{C}$ for $16 \mathrm{~s}$ to minimize heat denaturation of SP. The milk was cooled to $4^{\circ} \mathrm{C}$ and stored at $\leq 6^{\circ} \mathrm{C}$ in a 1,136 - $\mathrm{L}$ stainless steel tote (Metano IBC Services Inc., Perrineville, NJ) until MF processing. The second and third days were used to MF the skim milk using membranes with channel diameters of 4 or $6 \mathrm{~mm}$.

\section{Microfiltration Operation}

On the evening before MF processing, the pilot-scale MF system (Tetra Alcross M7, TetraPak Filtration Systems, Aarhus, Denmark) was cleaned as described by Hurt et al. (2010). Briefly, the nitric acid storage solution $(0.55 \%, \mathrm{vol} / \mathrm{vol})$ was flushed out of the system using $25^{\circ} \mathrm{C}$ reverse osmosis (RO) water until the flush water was neutral (15 min). The MF system was gradu- 
ally heated $\left(<10^{\circ} \mathrm{C} / \mathrm{min}\right)$ to $80^{\circ} \mathrm{C}$ using $85^{\circ} \mathrm{C} \mathrm{RO}$ water, Ultrasil 25 (Ecolab Inc., St. Paul, MN) was added to the system $(1.95 \%, \mathrm{vol} / \mathrm{vol})$, and the Ultrasil caustic solution was recirculated for $30 \mathrm{~min}$ with the feed and retentate recirculation pumps on. After cleaning, the system was gradually cooled $\left(<10^{\circ} \mathrm{C} / \mathrm{min}\right)$ to $50^{\circ} \mathrm{C}$ and the caustic solution was flushed out of the system using $25^{\circ} \mathrm{C}$ RO water until the flush water was neutral (15 $\min )$.

The system was equipped with either Membralox ceramic membranes with 4-mm round flow channels (EP3740, Pall Corp., East Hills, NY) or Membralox ceramic membranes with $6-\mathrm{mm}$ round flow channels (EP1960, Pall Corp.). Both membranes were made of zirconia and composed of a selective layer (nominal pore size of $100 \mathrm{~nm}$ ), an intermediate layer (nominal pore size of $0.8 \mu \mathrm{m}$ ), and a support structure (nominal pore size of $12 \mu \mathrm{m}$ ). For each membrane type, the system's stainless steel membrane module housed 3 membrane elements. The $4-\mathrm{mm}$ membranes contained 37 retentate flow channels per element that were $4 \mathrm{~mm}$ in diameter and $1.02 \mathrm{~m}$ in length for a total module membrane surface area of $1.41 \mathrm{~m}^{2}$. The $6-\mathrm{mm}$ membranes contained 19 retentate flow channels per element that were $6 \mathrm{~mm}$ in diameter and $1.02 \mathrm{~m}$ in length for a total module membrane surface area of $1.08 \mathrm{~m}^{2}$. Relevant measurements for both membranes are shown in Figure 1.

The MF system was identical to that described by Hurt et al. (2010), with the following exceptions: the membrane modules described above were used, a digital magnetic mass flow meter (model AM204DH, Yokogawa Electronic Corp., Tokyo, Japan) was used to measure the retentate removal rate, polypropylene beads (Borealis granulates, Pall Corp.) were used to fill the permeate side of the membrane module, and screened gaskets (40MPUS15, Twinco Inc., West Falls, $\mathrm{NY}$ ) were used to retain the beads within the module.
The retentate flow meter was added to improve control of the retentate flow rate, and consequently, the CF. The additions of the beads and gaskets were made so that the membrane could be cleaned in uniform transmembrane pressure mode (Hurt et al., 2010) to ensure that the permeate side of the membrane was thoroughly cleaned. Nongraded permeability membranes were used in this study because the 6 - $\mathrm{mm}$ membranes were not available with the graded permeability modification. When processing milk, the nongraded permeability membranes were not operated with recirculation of MF permeate. Previous results by Adams et al. (2015b) found that the 4-mm nongraded permeability membranes operated well without uniform transmembrane pressure.

Pressure gauges were mounted on the system to monitor retentate pressure at the membrane inlet $\left(\mathbf{P}_{\mathbf{R i}}\right)$, retentate pressure at the membrane outlet $\left(\mathbf{P}_{\mathbf{R o}}\right)$, and permeate pressure at the membrane inlet $\left(\mathbf{P}_{\mathbf{P i}_{\mathbf{i}}}\right)$. Permeate pressure at the membrane outlet $\left(\mathbf{P}_{\mathbf{P o}_{\mathbf{0}}}\right)$ was calculated by adding $10 \mathrm{kPa}$ to $\mathrm{P}_{\mathrm{Pi}}$ to account for the weight of the vertical column of liquid. On the morning of processing, the MF system was flushed with $50^{\circ} \mathrm{C}$ $\mathrm{RO}$ water to heat the system and remove the storage acid. A clean membrane water flux was measured using $50^{\circ} \mathrm{C} \mathrm{RO}$ water and pressure gauges were corrected to account for their vertical heights so that accurate transmembrane pressure (TMP) at the inlet and outlet and average TMP $\left(\mathbf{T M P} \mathbf{P}_{\mathbf{i}}, \mathbf{T M} \mathbf{P}_{\mathbf{o}}\right.$, and $\mathbf{T M P} \mathbf{P}_{\mathrm{avg}}$, respectively) could be calculated (Hurt et al., 2010). Initial MF processing conditions were then set on $\mathrm{RO}$ water. To do this, the retentate recirculation pump was turned on and controlled using a variable frequency drive (MC Series, model M12100C, Lenze AC Tech, Uxbridge, MA) to achieve an average cross-flow velocity of $7 \mathrm{~m} \cdot \mathrm{s}^{-1}$. The permeate valve was then opened to achieve a flux of $55 \mathrm{~kg} \cdot \mathrm{m}^{-2} \cdot \mathrm{h}^{-1}$ and the retentate valve
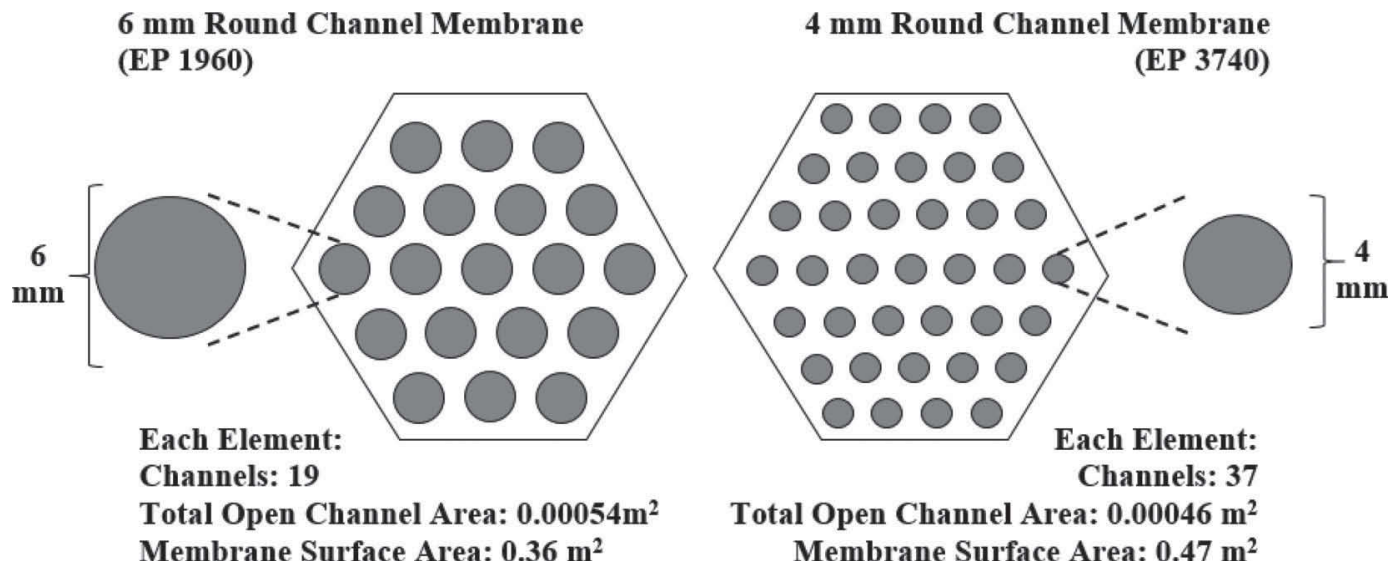

Figure 1. Cross-sectional views of 6-mm and 4-mm round channel membrane elements with relevant measurements. 
was opened to achieve a $\mathrm{CF}$ of $2.40 \times$ to target an initial retentate protein concentration of $7 \%$.

Once processing conditions were set, the skim milk was heated to $50^{\circ} \mathrm{C}$ by pumping through a plate heat exchanger (model 080-S, AGC Engineering) at $60^{\circ} \mathrm{C}$. A prefilter was placed in-line and downstream of the heat exchanger that was used to warm the skim milk as a precautionary measure to remove any possible debris in the milk that could damage the ceramic membranes. The prefilter consisted of a filter housing (Nexis, 30 $\mathrm{cm}$ length, Pall Corp.) and a $10-\mu \mathrm{m}$ polypropylene filter (Nexis T 10-30U-M7S, Pall Corp.). Skim milk was pumped directly from the prefilter into a $379-\mathrm{L}$ jacketed vat and the prefilter was discarded after use. The skim milk was held in the vat at $50^{\circ} \mathrm{C}$ for $15 \mathrm{~min}$ before the MF feed source was switched from $50^{\circ} \mathrm{C}$ RO water to $50^{\circ} \mathrm{C}$ skim milk $(360 \mathrm{~kg})$ and the $\mathrm{RO}$ water was flushed out of the system. Permeate and retentate were collected into standard 38-L stainless steel milk cans, weighed, and then discarded while flushing. In total, $180 \mathrm{~kg}$ of permeate, retentate, and $\mathrm{RO}$ water was collected to bring the protein concentration in the retentate recirculation loop to the target $7 \%$, as determined by an mid-infrared (MIR) spectrophotometer (Lactoscope FTIR Advanced, Delta Instruments, Drachten, the Netherlands). Once the water had been flushed from the system, the retentate and permeate were recycled back to the feed vat, and the remainder of the experiment was conducted in total recycle. While in recycle mode, the retentate removal rate was decreased each hour for $5 \mathrm{~h}$. Reducing the retentate removal rate increased the retentate protein concentration in the recirculation loop while maintaining the permeate flux at $55 \mathrm{~kg} \cdot \mathrm{m}^{-2} \cdot \mathrm{h}^{-1}$, thereby increasing the CF (Equation [2]):

$$
\mathrm{CF}=\frac{(\text { Retentate }+ \text { Permeate })}{\text { Retentate }} .
$$

Target retentate protein concentrations for the 5 steps were $7,8,9,10$, and $11.5 \%$. During the protein concentration-stepping procedure, permeate mass flux and $\mathrm{CF}$ were measured every $15 \mathrm{~min}$ by collecting retentate and permeate from the system into 2 tared 19-L buckets. After 2 min of collection, the buckets were weighed to the nearest gram using a balance (model MS32000L, Mettler Toledo, Bedford, MA) and the CF was calculated. Samples of permeate and retentate were collected and analyzed by MIR to monitor the composition every 15 min. After 45 min at each protein concentration, the retentate and permeate were collected continuously for 15 min into separate milk cans and samples for analytical testing were collected from each can. The permeate and retentate that remained after sampling were added back to the feed vat and the protein concentration was increased. An LRPC was reached when flux could no longer be maintained after increasing the retentate protein concentration. At this point, the system was flushed with RO water, a fouled water flux was determined with $50^{\circ} \mathrm{C} \mathrm{RO}$ water, and the MF system was cleaned as described by Hurt et al. (2010).

\section{Analytical Testing}

Proximate Analyses. Skim milk samples were collected before processing. Retentate and permeate samples were collected during processing from the retentate and permeate exits before going back to the feed tank and analyzed using a calibration for milk to rapidly estimate fat, anhydrous lactose, and true protein (TP) using MIR (Kaylegian et al., 2006). The MIR analysis was done to confirm that retentate protein concentrations remained near target values (i.e., 7, 8, 9, 10, or $11.5 \%$ ) during processing and to detect changes in SP passage in the permeate during a processing run. Skim milk TS, fat, total nitrogen (TN), NPN, and noncasein nitrogen $(\mathbf{N C N})$ were determined using forced-air oven drying (AOAC International, 2000; method 990.20; 33.2.44), ether extraction (AOAC International, 2000; method 989.05; 33.2.26), Kjeldahl (AOAC International, 2000; method 991.20; 33.2.11), Kjeldahl (AOAC International, 2000; method 991.21; 33.2.12), and Kjeldahl (AOAC International, 2000; method 998.05; 33.2.64), respectively. Skim milk NCN preparation was modified by increasing the amounts of sodium acetate $(1 \mathrm{~N})$ and acetic acid (10\% vol/vol) from $1 \mathrm{~mL}$ each to $5.5 \mathrm{~mL}$ each to fully precipitate casein (Wojciechowski and Barbano, 2015). Crude protein was calculated by multiplying TN by 6.38 , TP was calculated by subtracting NPN from TN and multiplying by 6.38 , CN was calculated by subtracting NCN from TN and multiplying by 6.38 , and SP was calculated by subtracting NPN from NCN and multiplying by 6.38. Retentate and permeate samples from each protein concentration step were analyzed for TS, TN, and NPN using the same methods as for the skim milk samples and TP was calculated. The $\mathrm{pH}$ of the skim milk, permeates, and retentates were measured during processing with a solid polymer electrode (HA405-DXK-S8/120, Mettler-Toledo) and an Accumet $915 \mathrm{pH}$ meter (Fisher Scientific, Pittsburgh, PA) that was calibrated at $50^{\circ} \mathrm{C}$ using standard $\mathrm{pH} 4$ and 7 buffer solutions (SB101, SB107, Fisher Scientific). All skim milk, permeate, and retentate TN, NPN, and NCN samples were immediately refrigerated at $<4^{\circ} \mathrm{C}$ and analyzed within $24 \mathrm{~h}$ of processing. All skim milk, permeate, and retentate 
TS and fat samples were immediately frozen at $-80^{\circ} \mathrm{C}$ until analysis.

Apparent Viscosity Measurement. Apparent viscosities of all skim milks and retentates were measured using a rotational viscometer (LV-DV2T, Brookfield Engineering Laboratories Inc., Middleboro, MA) equipped with a jacketed cup-and-bob fixture (Enhanced UL Adapter, Brookfield Engineering Laboratories Inc.). All skim milks and retentates were measured at $50 \pm 1^{\circ} \mathrm{C}$ at a constant shear rate of $73 \mathrm{~s}^{-1}$. Each sample was tempered in a water bath at $50^{\circ} \mathrm{C}$ for $5 \mathrm{~min}$ before being placed in the viscometer cup. Temperature was maintained by placing $16 \mathrm{~mL}$ of tempered sample into the cup and circulating $50^{\circ} \mathrm{C}$ water through the jacket during measurement. Each sample measurement reflected the average viscosity obtained under $30 \mathrm{~s}$ of shear after a 20-s shear equilibration period.

In addition, retentate apparent viscosities were measured at $4^{\circ} \mathrm{C}, 20^{\circ} \mathrm{C}$, and $50^{\circ} \mathrm{C}$ at a constant shear rate of $12 \mathrm{~s}^{-1}$. This testing was performed to determine the effect of temperature on retentate viscosity. The shear rate $\left(12 \mathrm{~s}^{-1}\right)$ was chosen to maximize the number of measurements made in which the torque on the viscometer's spindle was between 10 and $100 \%$ of its maximum range. Operating the viscometer within this range improves measurement accuracy, according to the manufacturer (Brookfield Engineering Laboratories, Inc., 2014). Viscosities were log-transformed and plotted in Excel (Microsoft Corp., Redmond, WA) at each temperature to derive linear regression equations to predict viscosity as a function of protein concentration.

Permeate Relative Whiteness Values. Hunter L (lightness) values for all permeates were determined in duplicate with a Macbeth Color-Eye spectrophotometer (model 2020; Kollmorgen Instruments Corp., Newburgh, NY) with ProPalette software (version 5.0; Kollmorgen Instruments Corp.). A white color tile was used as a reflectance standard and was measured at the beginning of each session to verify instrument performance. Hunter values were computed from the diffuse reflectance of light in the 360 to $750 \mathrm{~nm}$ range, at $10-\mathrm{nm}$ intervals, based on illuminant A. The measurements were made at $24 \pm 1^{\circ} \mathrm{C}$ using a glass cuvette with a 1-cm path length. Because the permeates were transparent and the cuvette was placed against a black background, these $\mathrm{L}$ values should not be considered whiteness values, but rather relative whiteness values $\left(\mathbf{L}_{\mathbf{R}}\right.$; Adams et al., 2015b).

\section{Hydrodynamic Conditions}

Reynolds Numbers. Reynolds numbers were calculated for the retentates at each protein concentration step according to Equation [1], where $\rho$ is the retentate density at $50^{\circ} \mathrm{C}\left(\mathrm{kg} \cdot \mathrm{m}^{-3}\right), \mathrm{D}_{\mathrm{h}}$ is the membrane hydraulic diameter $(0.004 \mathrm{~m}$ or $0.006 \mathrm{~m}), \mathrm{V}$ is the average retentate cross-flow velocity $\left(\mathrm{m} \cdot \mathrm{s}^{-1}\right)$, and $\mu$ is the retentate viscosity at $50^{\circ} \mathrm{C}(\mathrm{Pa} \cdot \mathrm{s})$. Retentate densities at $7,8,9$, 10 , and $11.5 \% \mathrm{TP}$ were calculated to be $1,038,1,042$, $1,046,1,050$, and $1,056 \mathrm{~kg} \cdot \mathrm{m}^{3}$, respectively, by interpolation of the milk density calculations described by the USDA (1965). This calculation predicted the density of $50^{\circ} \mathrm{C}$ skim MF retentate at $\mathrm{pH} 6.5$ observed by Solanki and Rizvi (2001) within $0.6 \%$ of the measured value and the density of $50^{\circ} \mathrm{C}$ skim MF retentate observed by Adams et al. (2015a) within $0.4 \%$ of the measured value.

Computational Fluid Dynamics. The turbulent fluid flow analysis module of COMSOL Multiphysics (version 4.3b, Stockholm, Sweden) was used to model radial velocity distributions in both the $4-\mathrm{mm}$ and 6-mm retentate flow channels at a retentate protein concentration of $9 \%$. Channel geometries were drawn in 3 dimensions using COMSOL, and meshing was set to the fluid dynamics preset value of "finer." The Reynoldsaveraged Navier-Stokes $\mathrm{k}-\omega$ model parameters were $\alpha=$ $0.52, \sigma_{\mathrm{k}}{ }^{*}=0.5, \sigma_{\omega}=0.5, \beta_{0}=0.072, \beta_{0}{ }^{*}=0.09, \kappa_{\mathrm{v}}$ $=0.41$, and $\mathrm{B}=5.2$. Assumptions included turbulent, stationary flow of an incompressible fluid with dynamic viscosity $=1.78 \mathrm{mPa} \cdot \mathrm{s}$ and density $=1,046 \mathrm{~kg} \cdot \mathrm{m}^{-3}$. Because axial flow through the membrane channels (i.e., retentate cross-flow) was approximately $500 \times$ the radial flow through the membrane channels (i.e., permeation through the membrane), radial flow was ignored. The channel inlet boundary condition was an average cross-flow velocity of $7 \mathrm{~m} \cdot \mathrm{s}^{-1}$ and the channel outlet boundary condition was a gauge pressure of 237 $\mathrm{kPa}$. A "wall functions" boundary condition was set at the wall. This approximated velocity near the wall and did not assume it to be equal to $0 \mathrm{~m} \cdot \mathrm{s}^{-1}$. This assumption reduces computational requirements and is a valid approach for practical engineering applications when flow is highly turbulent (COMSOL, 2013). A stationary iterative solver (400 iterations maximum) was used to solve the Navier-Stokes equations. Data were visualized by slicing a cross-sectional area from the center of each channel.

Retentate Recirculation Pump Energy. The energy required to operate the retentate recirculation pump at a retentate protein concentration of $9 \%$ was calculated according to Equation [3] (Cheryan, 1998), where $E_{Q}$ is the energy required per unit volume of permeate produced $\left(\mathrm{kW} \cdot \mathrm{h} \cdot \mathrm{m}^{-3}\right), \Delta \mathrm{P}$ is the longitudinal pressure drop across the membrane $(\mathrm{Pa}), \mathrm{Q}$ is the retentate recirculation rate $\left(\mathrm{m}^{3} \cdot \mathrm{s}^{-1}\right), \mathrm{J}$ is the flux $\left(\mathrm{L} \cdot \mathrm{m}^{-2} \cdot \mathrm{h}^{-1}\right), \mathrm{A}$ is the module membrane surface area 
$\left(\mathrm{m}^{2}\right)$, and $\eta$ is the pump efficiency (unitless). The value for $\eta$ was assumed to be 0.65 (Mulder, 1994):

$$
\mathrm{E}_{\mathrm{Q}}=\frac{\Delta \mathrm{P} \times \mathrm{Q}}{\mathrm{J} \times \mathrm{A} \times \eta}
$$

\section{Statistical Analysis}

Data were analyzed by ANOVA using the Proc GLM procedure of SAS (version 9.4, SAS Institute Inc., Cary, NC). To detect differences $(P<0.05)$ in composition among skim milks used with the different membranes, the general linear model was dependent variable = membrane + replicate + error, where replicate was considered a random variable. To detect differences $(P$ $<0.05)$ in processing variables, retentates, and permeates among membranes at a given retentate protein concentration, the model was dependent variable $=$ membrane + replicate + error, where replicate was a random variable. To determine if processing variables, retentate compositions, or permeate compositions changed as a function of retentate protein concentration, retentate protein concentration was treated as a continuous subplot variable in the split-plot ANOVA models. Distortion of the ANOVA by multicollinearity in the model was minimized by transforming the protein concentrations (Glantz and Slinker, 2001). Protein was transformed as follows: transformed protein $=$ protein $-[$ (highest protein concentration + lowest protein concentration)/2]. This transformation made the data set orthogonal with respect to protein concentration. The split-plot ANOVA model was dependent variable $=$ membrane + replicate + membrane $\times$ replicate + protein + membrane $\times$ protein + protein $\times$ protein + membrane $\times$ protein $\times$ protein + error. Because membrane was a whole-plot factor in the split block design, its significance was tested using membrane $x$ replicate as the error term.

\section{RESULTS AND DISCUSSION}

\section{Proximate Compositions of Skim Milk, Retentates, and Permeates}

Skim Milk Composition. The mean compositions of the skim milks used to feed the 4- and 6-mm membrane systems are shown in Table 1. The mean CN\% TP of the raw skim milk $(80.0 \pm 0.1 \%)$ and pasteurized skim milk were not different $(P>0.05)$, indicating that very little SP was bound to the casein micelles due to SP heat denaturation during pasteurization. The 4-mm system skim milk was slightly higher $(P<0.05)$ in SP than the $6-\mathrm{mm}$ system skim milk. This caused the
Table 1. Mean $(\mathrm{n}=3)$ composition $^{1}$ and apparent viscosities ${ }^{2}$ of skim milks used to feed the 4-mm and 6-mm round channel microfiltration processes

\begin{tabular}{lcccc}
\hline Item & $4 \mathrm{~mm}$ & $6 \mathrm{~mm}$ & $\mathrm{SE}$ & $\mathrm{R}^{2}$ \\
\hline TS (\%) & 9.263 & 9.288 & 0.016 & 0.87 \\
Fat (\%) & 0.133 & 0.133 & 0.012 & 0.43 \\
CP (\%) & 3.421 & 3.428 & 0.014 & 0.82 \\
NPN (\%) & 0.166 & 0.169 & 0.005 & 0.69 \\
NCN (\%) & 0.812 & 0.806 & 0.007 & 0.50 \\
TP (\%) & 3.255 & 3.258 & 0.010 & 0.94 \\
CN (\%) & 2.609 & 2.622 & 0.008 & 0.96 \\
SP (\%) & $0.646^{\mathrm{a}}$ & $0.636^{\mathrm{b}}$ & 0.002 & 0.94 \\
SP permeate portion (\%) & $0.663^{\mathrm{a}}$ & $0.653^{\mathrm{b}}$ & 0.002 & 0.94 \\
CN\% TP (\%) & $80.2^{\mathrm{b}}$ & $80.5^{\mathrm{a}}$ & 0.034 & 0.99 \\
pH & 6.46 & 6.46 & 0.016 & 0.87 \\
Apparent viscosity & 0.93 & 0.93 & 0.008 & 0.53 \\
\hline
\end{tabular}

$\overline{\mathrm{a}, \mathrm{b}}$ Means within a row not followed by the same letter are different $(P$ $<0.05)$.

${ }^{1} \mathrm{CP}=$ total $\mathrm{N} \times 6.38 ; \mathrm{NPN}=$ nonprotein $\mathrm{N} \times 6.38 ; \mathrm{NCN}=$ noncasein $\mathrm{N} \times 6.38 ; \mathrm{TP}=$ true protein $=\mathrm{CP}-\mathrm{NPN} ; \mathrm{CN}=\mathrm{TN}-\mathrm{NCN} ; \mathrm{SP}$ $=$ serum protein $=\mathrm{NCN}-\mathrm{NPN} ; \mathrm{SP}_{\text {permeate portion }}=[\mathrm{SP} /(100-\mathrm{CN})]$; $\mathrm{CN} \% \mathrm{TP}=(\mathrm{CN} / \mathrm{TP}) \times 100$.

${ }^{2} \mathrm{Viscosity}$ measured at $50^{\circ} \mathrm{C}$ at a shear rate of $73 \mathrm{~s}^{-1}$.

4-mm system skim milk SP in the permeate portion of the feed to the higher $(P<0.05)$ and $\mathrm{CN} \% \mathrm{TP}$ to be lower $(P<0.05)$ than those of the 6 -mm system skim milk. Because the difference in skim milk SP between the membrane systems was small $(0.01 \%)$ and assessing SP removal was not a goal of this study, this difference in SP (Table 1) was not considered important. No other differences $(P>0.05)$ in composition were noted between the skim milks used to feed the 2 systems.

Retentate Composition. The mean retentate compositions for both membrane systems at each protein concentration step are shown in Table 2. Within each protein group (i.e., $7,8,9,10$, or $11.5 \% \mathrm{TP}$ ), no differences $(P>0.05)$ in composition were noted between the retentates produced using the 4- and 6-mm systems (Table 2). As expected, when the CF was increased, retentate $\mathrm{CP}, \mathrm{NPN}, \mathrm{TP}$, and TS increased $(P<0.05)$ for both the 4 - and 6-mm membrane systems (Table $3)$. These increases were due only to changes in the $\mathrm{CF}$ and were not affected $(P>0.05)$ by the membrane used (Table 3).

Retentate $\mathrm{pH}$ decreased nonlinearly, as evidenced by a significant $(P<0.05)$ protein $\times$ protein term in the ANOVA model (Table 3). Although this decrease in $\mathrm{pH}$ was correlated with processing time, it was not thought to be due to microbial acid production over time. The trend in which the $\mathrm{pH}$ suddenly decreased from 6.46 to 6.37 as the retentate protein concentration exceeded $10 \%$ (Table 2) was repeatable among all 3 replicates in this study and has not been observed in other MF studies (Adams et al., 2015a,b) conducted using similar processing conditions with retentate protein concentra- 
Table 2. Mean $(\mathrm{n}=3)$ retentate composition ${ }^{1}$ during microfiltration of skim milk at $50^{\circ} \mathrm{C}$ using membranes with 4 -mm or 6 -mm channel diameters at $7,8,9,10$, or $11.5 \%$ protein in the retentate recirculation loop ${ }^{2}$

\begin{tabular}{|c|c|c|c|c|c|}
\hline Item & TS & $\mathrm{CP}$ & $\mathrm{NPN}$ & $\mathrm{TP}$ & $\mathrm{pH}$ \\
\hline \multicolumn{6}{|l|}{$7 \%$} \\
\hline $4 \mathrm{~mm}$ & 13.407 & 7.283 & 0.162 & 7.121 & 6.46 \\
\hline $6 \mathrm{~mm}$ & 13.401 & 7.317 & 0.166 & 7.151 & 6.46 \\
\hline $\mathrm{SE}$ & 0.122 & 0.148 & 0.009 & 0.149 & $<0.01$ \\
\hline $\mathrm{R}^{2}$ & 0.55 & 0.25 & 0.30 & 0.23 & $>0.99$ \\
\hline \multicolumn{6}{|l|}{$8 \%$} \\
\hline $4 \mathrm{~mm}$ & 14.488 & 8.311 & 0.160 & 8.151 & 6.46 \\
\hline $6 \mathrm{~mm}$ & 14.315 & 8.187 & 0.158 & 8.029 & 6.46 \\
\hline $\mathrm{SE}$ & 0.095 & 0.127 & 0.005 & 0.131 & $<0.01$ \\
\hline $\mathrm{R}^{2}$ & 0.75 & 0.71 & 0.90 & 0.68 & $>0.99$ \\
\hline \multicolumn{6}{|l|}{$9 \%$} \\
\hline $4 \mathrm{~mm}$ & 15.374 & 9.092 & 0.164 & 8.928 & 6.46 \\
\hline $6 \mathrm{~mm}$ & 15.478 & 9.218 & 0.170 & 9.048 & 6.46 \\
\hline SE & 0.130 & 0.159 & 0.006 & 0.164 & $<0.01$ \\
\hline $\mathrm{R}^{2}$ & 0.52 & 0.50 & 0.74 & 0.50 & $>0.99$ \\
\hline \multicolumn{6}{|l|}{$10 \%$} \\
\hline $4 \mathrm{~mm}$ & 16.401 & 10.070 & 0.164 & 9.906 & 6.45 \\
\hline $6 \mathrm{~mm}$ & 16.594 & 10.317 & 0.167 & 10.150 & 6.44 \\
\hline SE & 0.371 & 0.374 & 0.007 & 0.379 & $<0.01$ \\
\hline $\mathrm{R}^{2}$ & 0.39 & 0.32 & 0.26 & 0.31 & 0.60 \\
\hline \multicolumn{6}{|l|}{$11.5 \%$} \\
\hline $4 \mathrm{~mm}$ & 18.049 & 11.635 & 0.170 & 11.465 & 6.37 \\
\hline $6 \mathrm{~mm}$ & 18.064 & 11.687 & 0.175 & 11.511 & 6.37 \\
\hline $\mathrm{SE}$ & 0.268 & 0.261 & 0.013 & 0.256 & 0.02 \\
\hline $\mathrm{R}^{2}$ & 0.29 & 0.05 & 0.42 & 0.06 & 0.88 \\
\hline
\end{tabular}

${ }^{1} \mathrm{CP}=$ total $\mathrm{N} \times 6.38 ; \mathrm{NPN}=$ nonprotein $\mathrm{N} \times 6.38 ; \mathrm{TP}=$ true protein $=\mathrm{CP}-\mathrm{NPN}$.

${ }^{2}$ No differences within the same protein group in the retentate recirculation loop were detected $(P>0.05)$.

tions of $8.5 \%$. Anema (2009) showed that increasing the TS of skim milk from 9.6 to $19.2 \%$ at $50^{\circ} \mathrm{C}$ caused a $0.2-$ unit reduction in $\mathrm{pH}$. The reduction in $\mathrm{pH}$ was attrib- uted to the increase in ionic component concentrations of the milk and possibly calcium phosphate precipitation (Anema, 2009). Although ionic species not associ-

Table 3. Analysis of variance degrees of freedom and variance explained $(\%)^{1}$ for retentate and permeate compositions, retentate viscosity, and permeate color during microfiltration of skim milk at $50^{\circ} \mathrm{C}$ using membranes with 4 - $\mathrm{mm}$ or 6 -mm channel diameters at $7,8,9,10$, or $11.5 \%$ protein in the retentate recirculation loop

\begin{tabular}{|c|c|c|c|c|c|c|c|}
\hline \multirow[b]{2}{*}{ Response variable } & \multirow{2}{*}{$\begin{array}{l}\text { Whole plot }{ }^{2} \\
\text { Membrane } \\
(\mathrm{df}=1)\end{array}$} & \multicolumn{4}{|c|}{ Subplot } & \multirow[b]{2}{*}{$\begin{array}{c}\text { Error } \\
(\mathrm{df}=20)\end{array}$} & \multirow[b]{2}{*}{$\mathrm{R}^{2}$} \\
\hline & & $\begin{array}{l}\text { Protein } \\
(\mathrm{df}=1)\end{array}$ & $\begin{array}{c}\text { Membrane } \\
\times \text { protein } \\
(\mathrm{df}=1)\end{array}$ & $\begin{array}{l}\text { Protein } \\
\times \text { protein } \\
(\mathrm{df}=1)\end{array}$ & $\begin{array}{c}\text { Membrane } \\
\times \text { protein } \times \text { protein } \\
(\mathrm{df}=1)\end{array}$ & & \\
\hline \multicolumn{8}{|l|}{ Retentate } \\
\hline $\mathrm{CP}$ & $<0.01$ & $100.00^{*}$ & $<0.01$ & $<0.01$ & $<0.01$ & $<0.01$ & $>0.99$ \\
\hline NPN & 1.59 & $22.65^{*}$ & 0.39 & 3.72 & 0.15 & 71.50 & 0.60 \\
\hline $\mathrm{pH}$ & 0.23 & $37.76^{*}$ & 0.01 & $21.54^{*}$ & 0.28 & 40.18 & 0.68 \\
\hline Viscosity & 0.03 & $98.53^{*}$ & 0.34 & 0.13 & 0.16 & 0.81 & $>0.99$ \\
\hline \multicolumn{8}{|l|}{ Permeate } \\
\hline $\mathrm{CP}$ & 28.40 & 2.53 & $9.12^{*}$ & $37.84^{*}$ & $4.56^{*}$ & 17.55 & 0.84 \\
\hline NPN & 7.39 & $68.26^{*}$ & 0.80 & 3.30 & 0.06 & 20.17 & 0.87 \\
\hline True protein & 25.30 & 0.11 & $11.89^{*}$ & $37.60^{*}$ & $5.51^{*}$ & 19.59 & 0.84 \\
\hline $\mathrm{TS}$ & 31.94 & $13.06^{*}$ & $5.42^{*}$ & $33.32 *$ & $4.81 *$ & 11.45 & 0.90 \\
\hline
\end{tabular}

${ }^{1}$ Variance explained $=($ factor type III SS $) /($ membrane + protein + membrane $\times$ protein + protein $\times$ protein + membrane $\times$ protein $\times$ protein type III SS) $\times 100$.

${ }^{2}$ Whole-plot factor (membrane) significance was tested using membrane $\times$ replicate as the error term.

${ }^{3} \mathrm{~L}_{\mathrm{R}}$ value is an indicator of permeate turbidity; higher $\mathrm{L}_{\mathrm{R}}$ values indicate higher turbidity and whiteness.

*Factor was significant $(P<0.05)$ at determining component or color. 
ated with the casein micelles were not concentrated by $\mathrm{MF}$ in the present work, the $\mathrm{pH}$ reduction was also not as large as that observed by Anema (2009). Further, mixing of the lower $\mathrm{pH} 11.5 \% \mathrm{TP} \mathrm{MF}$ retentate and the lower $\mathrm{pH}$ MF permeate produced in the present work in a 1:3.13 to bring the concentration of TP back to that of skim milk resulted in an average increase in $\mathrm{pH}$ of 0.04 units at $50^{\circ} \mathrm{C}$ (data not shown), near that of the original milk $\mathrm{pH}$ (Table 1). This increase in $\mathrm{pH}$ of the mixture would not happen if the reduction of $\mathrm{pH}$ of the retentate and permeate was caused by microbial growth. Consequently, the $\mathrm{pH}$ decrease observed at high retentate protein concentrations (Table 2) may have been due to milk protein-mineral equilibrium changes due to concentration of the casein micelles. More work is needed to verify this hypothesis.

Permeate Composition. The mean permeate compositions for both membrane systems at each protein concentration step are shown in Table 4. Permeate produced using the 4 -mm system was lower $(P<0.05)$ in $\mathrm{CP}$ and TP than permeate produced using the 6-mm system when the target retentate protein concentration was below $11.5 \%$ (Table 4 ). The variation in permeate $\mathrm{TP}$ can be attributed to differences in membrane pore size manufacturing tolerances. Similar differences in protein passage between different ceramic MF membranes have been noted in a previous study (Adams et al., 2015b) in which only one membrane module for each membrane type was used for comparison. To make valid conclusions regarding differences in protein removal among membranes of different designs, it would be necessary to test different lots of each membrane of interest. When the retentate protein concentration was increased to $11.5 \%$, both membranes began to foul rapidly and no differences $(P>0.05)$ in $\mathrm{CP}$ or TP were detected between the systems. Permeate $\mathrm{CP}$ and TP initially increased $(P<0.05)$ with increasing retentate protein concentration, and then decreased $(P<0.05)$ as the membrane began to foul (Table 3). Beckman and Barbano (2013) noted that as retentate TP was increased from 4.48 to $7.71 \%$ during MF of skim milk using polymeric membranes, permeate SP increased from 0.19 to $0.32 \%$. Beckman and Barbano (2013) attributed the increase in permeate SP to a higher SP concentration near the surface of the membrane as the retentate TP increased. Because SP concentrations in the permeates of Beckman and Barbano (2013) and SP concentrations in the permeates in the present study (Table 4) were lower than in the skim milks used to feed the 2 studies' respective MF systems [skim milk $\mathrm{SP}=0.59 \%$ in Beckman and Barbano (2013) and Table 1, respectively], the initial increase in permeate TP with increasing retentate protein concentration (from $7 \%$ retentate $\mathrm{TP}$ to $10 \%$ retentate $\mathrm{TP}$ ) might be attributed to enhanced concentration polarization near the membrane surface when fouling was low. The extent of the changes in permeate TP was dependent on the membrane used, as evidenced by a membrane $\times$ protein interaction $(P<0.05$; Table 3$)$. Permeate TS also increased $(P<0.05)$ initially, and then decreased $(P<0.05)$ as the membrane began to foul due to differences in TP (Table 3). Permeate NPN increased ( $P$ $<0.05$ ) as retentate TP increased (Table 3). Permeate $\mathrm{pH}$ decreased in the same manner as retentate $\mathrm{pH}$ as retentate protein concentration increased, and can likely be explained by the same phenomenon.

\section{Permeate Relative Whiteness Values}

Colloidal casein micelles scatter light and cause skim milk to appear white. The presence of casein micelles in MF permeates, even at levels as low as $0.01 \%$ (wt/ wt), has been demonstrated to increase $L_{R}$ values and make the permeates whiter relative to permeates with lower levels of casein micelle contamination (Adams et al., 2015b). Skim milk permeates produced using a MF membrane that retained almost all of the casein micelles have exhibited $\mathrm{L}_{\mathrm{R}}$ values below 20 (Zulewska et al., 2009; Adams et al., 2015b) and low levels of casein in the permeate $(<0.005 \%)$, and appeared less opaque than skim milk permeates produced using a membrane that passed casein micelles into the permeate (Adams et al., 2015b). In the present study, all permeates were clear and all had $\mathrm{L}_{\mathrm{R}}$ values below 20 (Table 4 ). This suggested that few to no casein micelles were present in the MF permeates produced by both membranes and that differences in protein passage between membranes were due either to SP or soluble casein.

\section{Apparent Viscosities of Skim Milk and Retentates}

Skim milk apparent viscosity ( shear rate $=73 \mathrm{~s}^{-1}$ ) at $50^{\circ} \mathrm{C}$ was $0.93 \mathrm{mPa} \cdot \mathrm{s}$ (Table 1 ), similar to the viscosity of skim milk reported by Fernandez-Martin (1972). Retentate apparent viscosities (shear rate $=73 \mathrm{~s}^{-1}$ ) at $50^{\circ} \mathrm{C}$ increased $(P<0.05)$ with increasing retentate protein concentrations (Table 3 ) but were not affected by the membrane type (Tables 2, 3). Compared with skim milk MF retentate, apparent viscosities measured by Solanki and Rizvi (2001) ( $\mathrm{pH}$ adjusted to 6.5 with glucono- $\delta$-lactone, $50^{\circ} \mathrm{C}$, shear rate $=1,350 \mathrm{~s}^{-1}$ ), retentate viscosities in the present study were about $7 \%$ higher at the same TS concentration. Skim milk MF retentates with casein concentrations $<10 \%$ behave as Newtonian liquids above $40^{\circ} \mathrm{C}$, but retentates with casein concentrations above $12.5 \%$ exhibited mild shear thinning at $60^{\circ} \mathrm{C}$ (Sauer et al., 2012). Because the highest retentate casein concentrations in the present study 
Table 4. Mean $(\mathrm{n}=3)$ permeate composition ${ }^{1}$ and relative whiteness values $\left(\mathrm{L}_{\mathrm{R}}\right)^{2}$ during microfiltration of skim milk at $50^{\circ} \mathrm{C}$ using membranes with $4-\mathrm{mm}$ or 6 -mm channel diameters at $7,8,9,10$, or $11.5 \%$ protein in the retentate recirculation loop

\begin{tabular}{|c|c|c|c|c|c|c|}
\hline Item & TS & $\mathrm{CP}$ & NPN & $\mathrm{TP}$ & $\mathrm{pH}$ & $\mathrm{L}_{\mathrm{R}}$ \\
\hline \multicolumn{7}{|l|}{$7 \%$} \\
\hline $4 \mathrm{~mm}$ & 6.366 & $0.664^{\mathrm{b}}$ & $0.166^{\mathrm{b}}$ & $0.498^{\mathrm{b}}$ & 6.51 & $19.903^{\mathrm{a}}$ \\
\hline $6 \mathrm{~mm}$ & 6.430 & $0.699^{\mathrm{a}}$ & $0.171^{\mathrm{a}}$ & $0.528^{\mathrm{a}}$ & 6.51 & $19.873^{\mathrm{b}}$ \\
\hline SE & 0.020 & 0.007 & $<0.001$ & 0.008 & $<0.01$ & 0.007 \\
\hline $\mathrm{R}^{2}$ & 0.89 & 0.94 & 0.98 & 0.91 & 0.98 & $>0.99$ \\
\hline \multicolumn{7}{|l|}{$8 \%$} \\
\hline $4 \mathrm{~mm}$ & 6.386 & $0.677^{\mathrm{b}}$ & 0.168 & $0.509^{\mathrm{b}}$ & 6.51 & 19.904 \\
\hline $6 \mathrm{~mm}$ & 6.472 & $0.708^{\mathrm{a}}$ & 0.170 & $0.538^{\mathrm{a}}$ & 6.52 & 19.897 \\
\hline $\mathrm{SE}$ & 0.026 & 0.006 & $<0.001$ & 0.006 & 0.01 & 0.008 \\
\hline $\mathrm{R}^{2}$ & 0.89 & 0.95 & 0.98 & 0.95 & 0.85 & $>0.99$ \\
\hline \multicolumn{7}{|l|}{$9 \%$} \\
\hline $4 \mathrm{~mm}$ & 6.424 & $0.689^{\mathrm{b}}$ & 0.174 & $0.515^{\mathrm{b}}$ & 6.51 & 19.914 \\
\hline $6 \mathrm{~mm}$ & 6.501 & $0.720^{\mathrm{a}}$ & 0.177 & $0.543^{\mathrm{a}}$ & 6.52 & 19.888 \\
\hline SE & 0.041 & 0.007 & 0.002 & 0.006 & 0.01 & 0.020 \\
\hline $\mathrm{R}^{2}$ & 0.73 & 0.94 & 0.87 & 0.96 & 0.77 & 0.98 \\
\hline \multicolumn{7}{|l|}{$10 \%$} \\
\hline $4 \mathrm{~mm}$ & 6.443 & $0.694^{\mathrm{b}}$ & $0.172^{\mathrm{b}}$ & $0.522^{\mathrm{b}}$ & 6.50 & 19.904 \\
\hline $6 \mathrm{~mm}$ & 6.496 & $0.719^{\mathrm{a}}$ & $0.180^{\mathrm{a}}$ & $0.539^{\mathrm{a}}$ & 6.50 & 19.894 \\
\hline $\mathrm{SE}$ & 0.023 & 0.001 & 0.002 & 0.002 & 0.01 & 0.009 \\
\hline $\mathrm{R}^{2}$ & 0.82 & $>0.99$ & 0.97 & $>0.99$ & 0.50 & $>0.99$ \\
\hline \multicolumn{7}{|l|}{$11.5 \%$} \\
\hline $4 \mathrm{~mm}$ & 6.429 & 0.686 & 0.176 & 0.510 & 6.46 & 19.897 \\
\hline $6 \mathrm{~mm}$ & 6.411 & 0.670 & 0.180 & 0.490 & 6.45 & 19.865 \\
\hline $\mathrm{SE}$ & 0.044 & 0.027 & 0.004 & 0.029 & 0.04 & 0.021 \\
\hline $\mathrm{R}^{2}$ & 0.37 & 0.38 & 0.79 & 0.42 & 0.65 & 0.96 \\
\hline
\end{tabular}

a,b Means within the same protein group not followed by the same letter are different $(P<0.05)$.

${ }^{1} \mathrm{CP}=$ total $\mathrm{N} \times 6.38 ; \mathrm{NPN}=$ nonprotein $\mathrm{N} \times 6.38 ; \mathrm{TP}=$ true protein $=\mathrm{CP}-\mathrm{NPN}$.

${ }^{2}$ Higher $\mathrm{L}_{\mathrm{R}}$ values indicate higher turbidity and whiteness.

would have been between 10 and $12.5 \%$, differences in apparent viscosity between the present study and that of Solanki and Rizvi (2001) could be due to differences in measurement systems, differences in shear rates used, or a combination of the two.

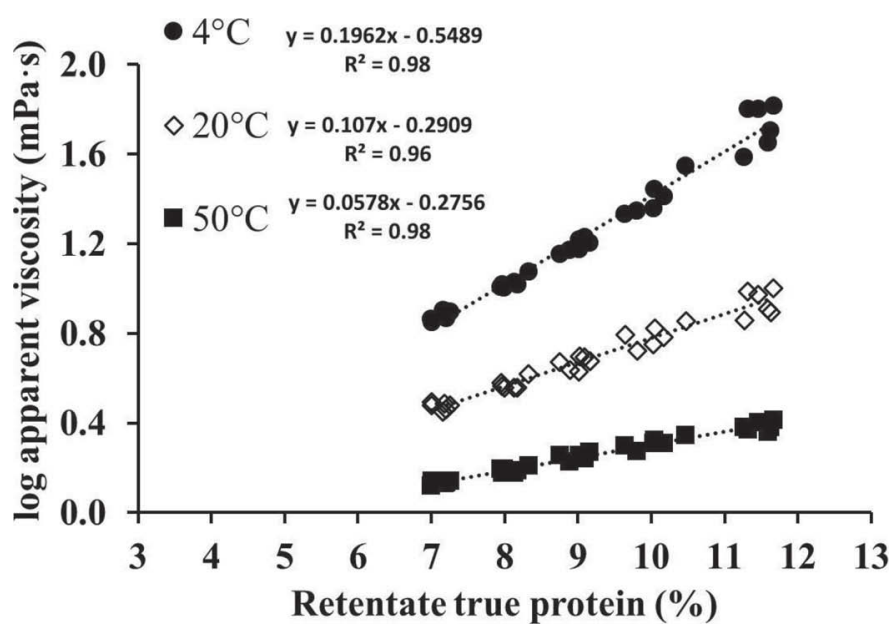

Figure 2. Retentate log apparent viscosity ( shear rate $=12 \mathrm{~s}^{-1}$ ) as a function of retentate protein concentration at $4^{\circ} \mathrm{C}, 20^{\circ} \mathrm{C}$, and $50^{\circ} \mathrm{C}$. Data from all 3 replicates are shown.
Retentate viscosities were also measured at 4, 20, and $50^{\circ} \mathrm{C}$ at a shear rate of $12 \mathrm{~s}^{-1}$ and $\log$ viscosities were plotted as a function of TP concentration at each temperature (Figure 2). Viscosity increased exponentially with decreasing temperature, as was expected (Sauer et al., 2012). Amelia and Barbano (2013) noted that high protein micellar casein concentrates $(22 \% \mathrm{TS}, 18 \%$ $\mathrm{TP}$ ) formed thermo-reversible gels when stored at $4^{\circ} \mathrm{C}$. Whether or not MF retentates form these gels would be a practical concern in a manufacturing facility. Liquid MF retentates may need to be held at $<4^{\circ} \mathrm{C}$ after processing. If the retentate forms a gel upon cooling, it may be difficult to pump from a holding tank to another point in the manufacturing facility. None of the retentates in the present study exhibited gel-like behavior when refrigerated for up to $72 \mathrm{~h}$, so gelling is not expected to be a problem with skim milk MF retentates at TP concentrations below $11.5 \%$.

\section{MF Processing Data}

Temperature was maintained at $50^{\circ} \mathrm{C}$ and was not affected $(P>0.05)$ by the membrane used or retentate protein concentration (Table 5). Permeate flux was maintained at $55 \mathrm{~kg} \cdot \mathrm{m}^{-2} \cdot \mathrm{h}^{-1}$ throughout the study. Increasing the retentate protein concentration 
Table 5. Analysis of variance degrees of freedom and variance explained $(\%)^{1}$ for processing parameters ${ }^{2}$ during microfiltration of skim milk at $50^{\circ} \mathrm{C}$ using membranes with 4 -mm or 6 - $\mathrm{mm}$ channel diameters at $7,8,9,10$, or $11.5 \%$ protein in the retentate recirculation loop

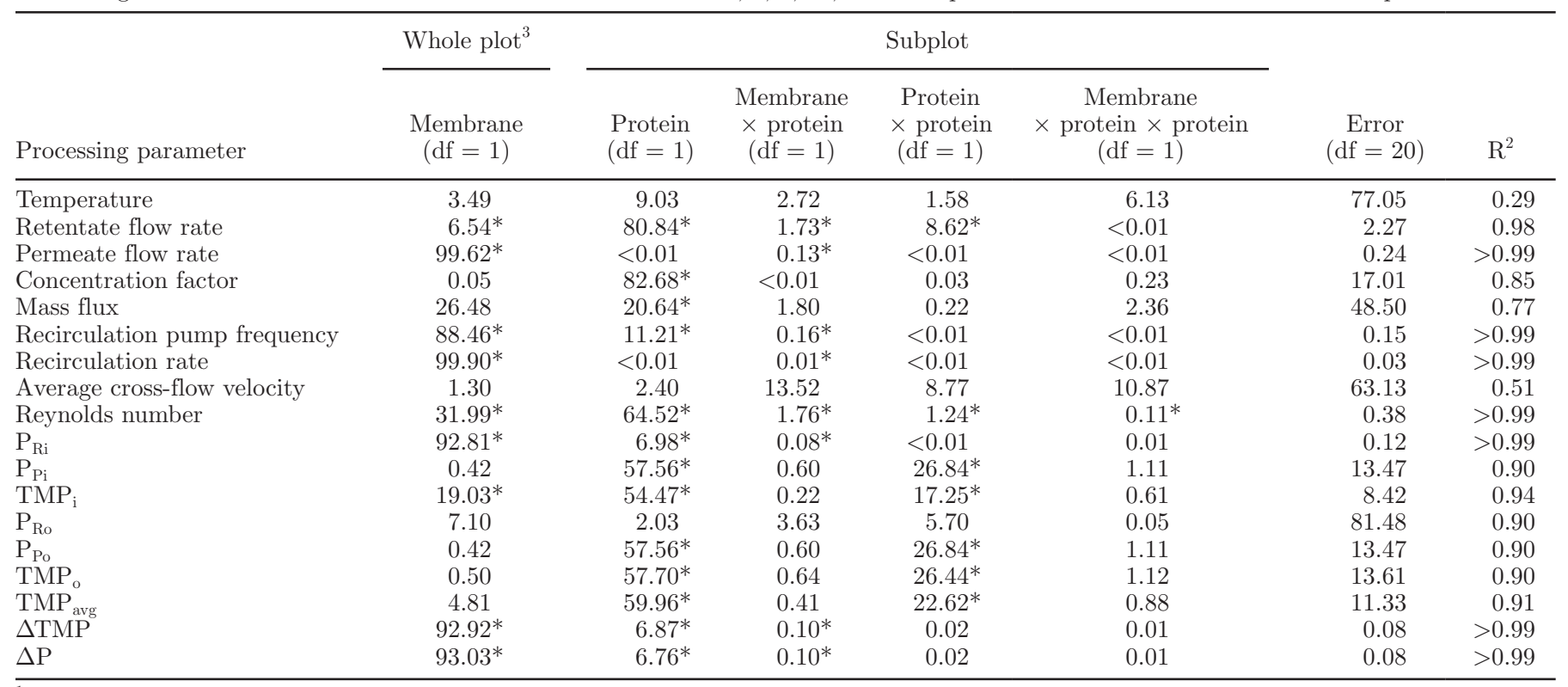

${ }^{1}$ Variance explained $=($ factor type III SS $) /($ membrane + protein + membrane $\times$ protein + protein $\times$ protein + membrane $\times$ protein $\times$ protein type III SS) $\times 100$.

${ }^{2} \mathrm{P}_{\mathrm{Ri}}=$ inlet retentate pressure; $\mathrm{P}_{\mathrm{P}_{\mathrm{i}}}=$ inlet permeate pressure; $\mathrm{TMP}_{\mathrm{i}}=$ transmembrane pressure at the inlet; $\mathrm{P}_{\mathrm{Ro}}=$ outlet retentate pressure; $\mathrm{P}_{\mathrm{Po}_{\mathrm{o}}}$ $=$ outlet permeate pressure; $\mathrm{TMP}_{\mathrm{o}}=$ transmembrane pressure at the outlet; $\mathrm{TMP}_{\text {avg }}=$ average transmembrane pressure $=\left(\mathrm{TMP}_{\mathrm{i}}+\mathrm{TMP}_{\mathrm{o}}\right) / 2 ;$ $\Delta \mathrm{TMP}=\mathrm{TMP}_{\mathrm{i}}-\mathrm{TMP}_{\mathrm{o}} ; \Delta \mathrm{P}=\mathrm{P}_{\mathrm{Ri}}-\mathrm{P}_{\mathrm{Ro}}$.

${ }^{3}$ Whole-plot factor (membrane) significance was tested using membrane $\times$ replicate as the error term.

*Factor was significant $(P<0.05)$ at determining processing parameter.

caused a slight decrease $(P<0.05)$ in permeate flux (flux $>52.5 \mathrm{~kg} \cdot \mathrm{m}^{-2} \cdot \mathrm{h}^{-1}$ ) as fouling progressed near the end of the $11.5 \%$ protein step. The permeate removal rate was lower $(P<0.05)$ for the 6 -mm system because the membrane surface area was lower and flux was constant. Because flux was controlled, retentate protein concentration was adjusted by decreasing ( $P$ $<0.05$ ) the retentate removal rate (i.e., increasing the $\mathrm{CF}$; Table 5). The retentate removal rate was lower $(P$ $<0.05)$ for the $6-\mathrm{mm}$ system because the membrane surface area was lower (Table 5).

\section{Pressures}

At each retentate protein concentration, the 4-mm system $\mathrm{P}_{\mathrm{Ri}}$ was higher $(P<0.05)$ than the $6-\mathrm{mm}$ system $\mathrm{P}_{\mathrm{Ri}}$ (Table 6). Because no differences $(P>0.05)$ in $\mathrm{P}_{\mathrm{Ro}}$ between the 4-mm and 6-mm systems were observed, $\Delta \mathrm{P}$ was only affected by $\mathrm{P}_{\mathrm{Ri}}$ and was higher $(P$ $<0.05)$ for the $4-\mathrm{mm}$ system at each retentate protein concentration (Table 6). The differences in $\mathrm{P}_{\mathrm{Ri}}$ and $\Delta \mathrm{P}$ observed betweenw the systems in this study were due to the difference in membrane channel diameter. In a round flow channel, $\Delta \mathrm{P}$ is directly proportional to cross-flow velocity (i.e., retentate recirculation rate) and inversely proportional to channel diameter. In laminar flow, the Hagen-Poiseuille equation (Equation [4]) can be used to predict how $\Delta \mathrm{P}$ changes over the length, L, of a channel as a function of recirculation rate $(\mathrm{Q})$, channel hydraulic diameter $\left(\mathrm{D}_{\mathrm{h}}\right)$, and fluid viscosity $(\mu)$ :

$$
\Delta \mathrm{P}=\frac{128 \mu \mathrm{LQ}}{\pi \mathrm{D}_{\mathrm{h}}^{4}}
$$

Because flow was highly turbulent $(\operatorname{Re}>4,000)$, the Hagen-Poiseuille equation cannot be used in this instance, but the direction of the relationship described by the equation remains valid. Relative to $4-\mathrm{mm}$ ceramic Membralox GP membranes, Hurt et al. (2015) observed that 3-mm Membralox GP membranes had a lower average cross-flow velocity when operated at the same $\Delta \mathrm{P}(220 \mathrm{kPa})$ when microfiltering milk protein concentrate. This relationship implies that at a constant retentate viscosity and $\Delta \mathrm{P}$, a system equipped with 6 -mm membrane could be operated at a higher crossflow velocity than a system with 4 -mm membranes.

Both $\mathrm{P}_{\mathrm{Ri}}$ and $\Delta \mathrm{P}$ increased $(P<0.05)$ with increasing retentate protein concentration due to the increase in retentate viscosity (Table 7 ). Because $\mathrm{P}_{\mathrm{Ri}}$ was higher 
for the 4-mm system than the 6-mm system, $\mathrm{P}_{\mathrm{Pi}}$ and $\mathrm{P}_{\mathrm{P}_{\mathrm{o}}}$ were higher $(P<0.05)$ for the 4 -mm system before the membranes began to foul (i.e., retentate protein $<10 \%$ ) (Table 6). Permeate pressures $\left(\mathrm{P}_{\mathrm{Pi}}\right.$ and $\left.\mathrm{P}_{\mathrm{Po}_{\mathrm{o}}}\right)$ decreased nonlinearly $(P<0.05)$ as retentate protein concentration increased due to an increase in concentration polarization and membrane fouling (Table 5). The decreases in permeate pressures and increases in $\mathrm{P}_{\mathrm{Ri}}$ caused by higher retentate protein concentrations caused $\mathrm{TMP}_{\mathrm{i}}, \mathrm{TMP}_{\mathrm{o}}$, and $\mathrm{TMP}_{\text {avg }}$ to increase $(P<$ 0.05 ) at higher retentate protein concentrations (Table 5). Because $\mathrm{TMP}_{\mathrm{i}}$ was calculated based on $\mathrm{P}_{\mathrm{Ri}}, \mathrm{TMP}_{\mathrm{i}}$ was higher for the 4-mm membrane before membrane fouling (i.e., retentate protein $<10 \%$ ).

Negative $\mathrm{TMP}_{\mathrm{o}}$ (Table 6) indicated Starling flow, or flow from the permeate side of the membrane to the retentate side of the membrane (Zulewska et al., 2009), at the membrane outlets in both systems. This condition is detrimental to the MF process because it reduces the amount of membrane area that can be used for separation. Starling flow was less severe [i.e., $\mathrm{TMP}_{\mathrm{o}}$ was higher $(P<0.05)]$ in the 6 -mm system at the 7,8 , and $9 \%$ retentate protein concentrations (Table 6 ). Starling flow was resolved as $\mathrm{P}_{\mathrm{Pi}_{\mathrm{i}}}$ and $\mathrm{P}_{\mathrm{P}_{\mathrm{o}}}$ began to decrease due to membrane fouling at $10 \%$ retentate protein (Table $6)$. Because $\mathrm{P}_{\mathrm{Ro}}$ was constant, the enhanced Starling flow observed in the 4-mm system was due to that system's higher permeate pressure caused by higher $\mathrm{P}_{\mathrm{Ri}}$.

\section{Hydrodynamic Conditions}

Because average cross-flow velocity was controlled in this study, it was not affected $(P>0.05)$ by the membrane used or the retentate protein concentration (Table 7). Because the cross-flow velocity was constant and the total open channel area of the 6 - $\mathrm{mm}$ membrane was higher than that of the 4-mm membrane (Figure $1)$, the retentate recirculation rate required to achieve the target cross-flow velocity was higher $(P<0.05)$ for the 6 -mm system (Tables 5 and 7 ). Retentate recirculation rates tended to decrease with increasing retentate protein concentration in the $4-\mathrm{mm}$ membrane and increase with increasing retentate TP concentration in the 6 -mm membranes (Table 7). These differences were small $(<0.4 \%)$ and only statistically detected because of the low variation of the retentate recirculation rate (Table 5). The retentate recirculation pump was equipped with a variable frequency drive, which allowed us to control the average cross-flow velocity by increasing or decreasing pump frequency. The pump frequency required to maintain the average cross-flow velocity was higher for the 4-mm membranes at all re-

Table 6. Mean $(\mathrm{n}=3)$ gauge pressures ${ }^{1}(\mathrm{kPa})$ during microfiltration of skim milk at $50^{\circ} \mathrm{C}$ using membranes with 4-mm or 6-mm channel diameters at $7,8,9,10$, or $11.5 \%$ protein in the retentate recirculation loop

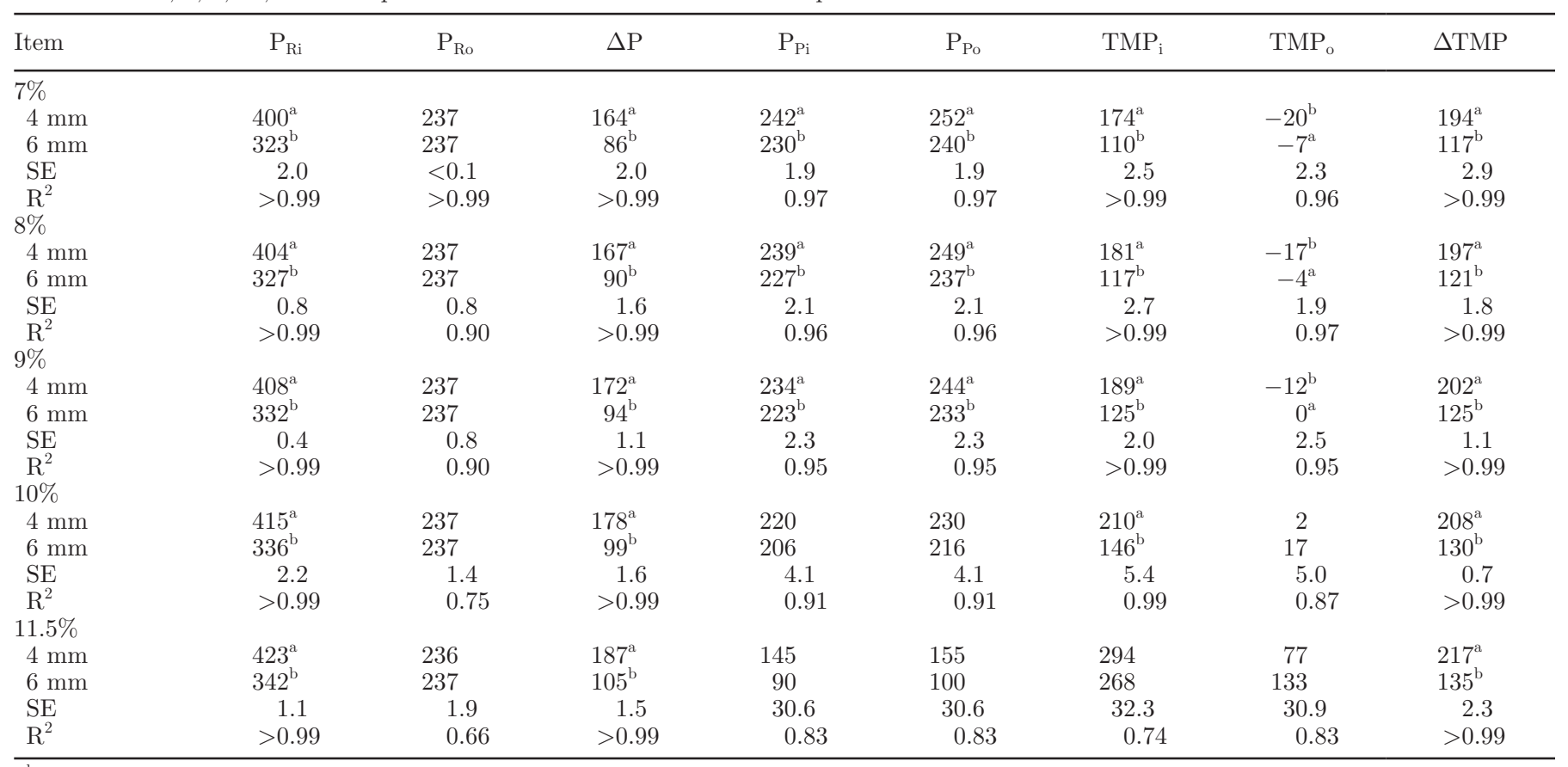

${ }^{\mathrm{a}, \mathrm{b}}$ Means within the same protein group not followed by the same letter are different $(P<0.05)$.

${ }^{1} \mathrm{P}_{\mathrm{Ri}}=$ inlet retentate pressure; $\mathrm{P}_{\mathrm{Ro}}=$ outlet retentate pressure; $\Delta \mathrm{P}=\mathrm{P}_{\mathrm{Ri}}-\mathrm{P}_{\mathrm{Ro}} ; \mathrm{P}_{\mathrm{Pi}}=$ inlet permeate pressure; $\mathrm{P}_{\mathrm{po}}=$ outlet permeate pressure; $\mathrm{TMP}_{\mathrm{i}}=$ transmembrane pressure at the inlet; $\mathrm{TMP}_{\mathrm{o}}=$ transmembrane pressure at the outlet; $\Delta \mathrm{TMP}=\mathrm{TMP}_{\mathrm{i}}-\mathrm{TMP}_{\mathrm{o}}$. 
tentate protein concentration steps (Tables 5 and 7 ). As retentate protein concentration increased, retentate viscosity increased and the pump frequency had to be increased to maintain cross-flow velocity (Tables 5 and $7)$. The significant membrane $\times$ protein term in the ANOVA model (Table 5) suggests that the rate of increase in frequency was higher for the 4-mm membrane than it was for the 6 -mm membrane. Reynolds numbers were calculated for both membranes at each protein concentration step. Because cross-flow velocity was constant, Re were only affected by the channel diameter, retentate density, and retentate viscosity. At any given retentate protein concentration, the 6 -mm system Re was higher than that of the $4-\mathrm{mm}$ system (Table 7 ) due to the increase in turbulence caused by the larger channel diameter (Equation [1]).

The radial shear rate and velocity distributions within the 4- and 6-mm membrane channels are shown in Figure 3. As expected, shear rates were highest and velocities were lowest near the membrane surface in both channels. Decreasing the channel diameter at a constant cross-flow velocity should increase the shear rate at the membrane surface (Hurt et al., 2015). Shear rate at the membrane surface was slightly higher for the $4-\mathrm{mm}$ membrane $\left(17,300 \mathrm{~s}^{-1}\right)$ than for the $6-\mathrm{mm}$ membrane $\left(14,900 \mathrm{~s}^{-1}\right)$, but velocity profiles were similar between the 2 channel diameters (Figure 3 ).

\section{LRPC}

As the retentate protein concentration increases, higher concentrations of casein micelles are present in the retentate recirculation loop and near the surface of the membrane. This increases concentration polarization, which leads to membrane fouling. The concept of critical, sustainable, and limiting fluxes is well documented (Bacchin et al., 2006; Hurt et al., 2015). However, their retentate protein counterparts (critical, sustainable, and limiting retentate protein concentrations) are not as widely studied. The LRPC, like the LF, will depend on the hydrodynamic conditions of the system and the viscosity of the retentate. Because the 6-mm system was operated at a higher Re (Table 7), it might be expected that the additional turbulence would increase

Table 7. Mean $(\mathrm{n}=3)$ retentate flow dynamic data during microfiltration of skim milk at $50^{\circ} \mathrm{C}$ using membranes with 4 -mm or 6 -mm channel diameters at $7,8,9,10$, or $11.5 \%$ protein in the retentate recirculation loop

\begin{tabular}{|c|c|c|c|c|c|}
\hline Item & $\begin{array}{c}\text { Recirculation } \\
\text { rate } \\
\left(\mathrm{L} \cdot \mathrm{min}^{-1}\right)\end{array}$ & $\begin{array}{l}\text { Average cross- } \\
\text { flow velocity } \\
\left(\mathrm{m} \cdot \mathrm{s}^{-1}\right)\end{array}$ & $\begin{array}{l}\text { Recirculation } \\
\text { pump frequency } \\
(\mathrm{Hz})\end{array}$ & $\begin{array}{l}\text { Apparent } \\
\text { viscosity } \\
(\mathrm{mPa} \cdot \mathrm{s})^{1}\end{array}$ & $\begin{array}{c}\text { Reynolds } \\
\text { number } \\
(-)^{2}\end{array}$ \\
\hline \multicolumn{6}{|l|}{$7 \%$} \\
\hline $4 \mathrm{~mm}$ & $587.8^{\mathrm{b}}$ & 7.02 & $58.1^{\mathrm{a}}$ & 1.38 & $21,200^{\mathrm{b}}$ \\
\hline $6 \mathrm{~mm}$ & $676.3^{\mathrm{a}}$ & 6.99 & $52.4^{\mathrm{b}}$ & 1.37 & $31,700^{\mathrm{a}}$ \\
\hline $\mathrm{SE}$ & 2.19 & 0.03 & 0.13 & 0.04 & 765 \\
\hline $\mathrm{R}^{2}$ & $>0.99$ & 0.61 & $>0.99$ & 0.01 & $>0.99$ \\
\hline \multicolumn{6}{|l|}{$8 \%$} \\
\hline $4 \mathrm{~mm}$ & $586.7^{\mathrm{b}}$ & $7.01^{\mathrm{a}}$ & $58.5^{\mathrm{a}}$ & 1.58 & $18,500^{\mathrm{b}}$ \\
\hline $6 \mathrm{~mm}$ & $676.5^{\mathrm{a}}$ & $7.00^{\mathrm{b}}$ & $52.8^{\mathrm{b}}$ & 1.55 & $28,300^{\mathrm{a}}$ \\
\hline $\mathrm{SE}$ & 0.16 & $<0.01$ & 0.13 & 0.01 & 145 \\
\hline $\mathrm{R}^{2}$ & $>0.99$ & 0.98 & $>0.99$ & 0.85 & $>0.99$ \\
\hline \multicolumn{6}{|l|}{$9 \%$} \\
\hline $4 \mathrm{~mm}$ & $586.3^{\mathrm{b}}$ & 7.01 & $58.9^{\mathrm{a}}$ & 1.79 & $16,300^{\mathrm{b}}$ \\
\hline $6 \mathrm{~mm}$ & $676.8^{\mathrm{a}}$ & 7.00 & $53.2^{\mathrm{b}}$ & 1.78 & $24,600^{\mathrm{a}}$ \\
\hline $\mathrm{SE}$ & 0.93 & 0.01 & 0.09 & 0.05 & 567 \\
\hline $\mathrm{R}^{2}$ & $>0.99$ & 0.39 & $>0.99$ & 0.29 & $>0.99$ \\
\hline \multicolumn{6}{|l|}{$10 \%$} \\
\hline $4 \mathrm{~mm}$ & $585.8^{\mathrm{b}}$ & 7.00 & $59.6^{\mathrm{a}}$ & 2.04 & $14,400^{\mathrm{b}}$ \\
\hline $6 \mathrm{~mm}$ & $676.9^{\mathrm{a}}$ & 7.00 & $53.6^{\mathrm{b}}$ & 2.09 & $21,200^{\mathrm{a}}$ \\
\hline $\mathrm{SE}$ & 1.01 & 0.01 & 0.30 & 0.16 & 1,451 \\
\hline $\mathrm{R}^{2}$ & $>0.99$ & 0.09 & $>0.99$ & 0.26 & 0.94 \\
\hline \multicolumn{6}{|l|}{$11.5 \%$} \\
\hline $4 \mathrm{~mm}$ & $586.8^{\mathrm{b}}$ & 7.01 & $60.3^{\mathrm{a}}$ & 2.51 & $11,800^{\mathrm{b}}$ \\
\hline $6 \mathrm{~mm}$ & $676.9^{\mathrm{a}}$ & 7.00 & $54.2^{\mathrm{b}}$ & 2.34 & $19,000^{\mathrm{a}}$ \\
\hline SE & 0.46 & $<0.01$ & 0.14 & 0.07 & 472 \\
\hline $\mathrm{R}^{2}$ & $>0.99$ & 0.87 & $>0.99$ & 0.80 & $>0.99$ \\
\hline
\end{tabular}

${ }^{a, b}$ Means within the same protein group not followed by the same letter are different $(P<0.05)$.

${ }^{1}$ Viscosity measured at $50^{\circ} \mathrm{C}$ at a shear rate of $73 \mathrm{~s}^{-1}$.

${ }^{2}$ Reynolds number $=$ density $\left(\mathrm{kg} \cdot \mathrm{m}^{-3}\right) \times$ hydraulic diameter $(0.004$ or $0.006 \mathrm{~m}) \times$ average cross-flow velocity $\left(\mathrm{m} \cdot \mathrm{s}^{-1}\right) /$ retentate viscosity $(\mathrm{Pa} \cdot \mathrm{s})$. 

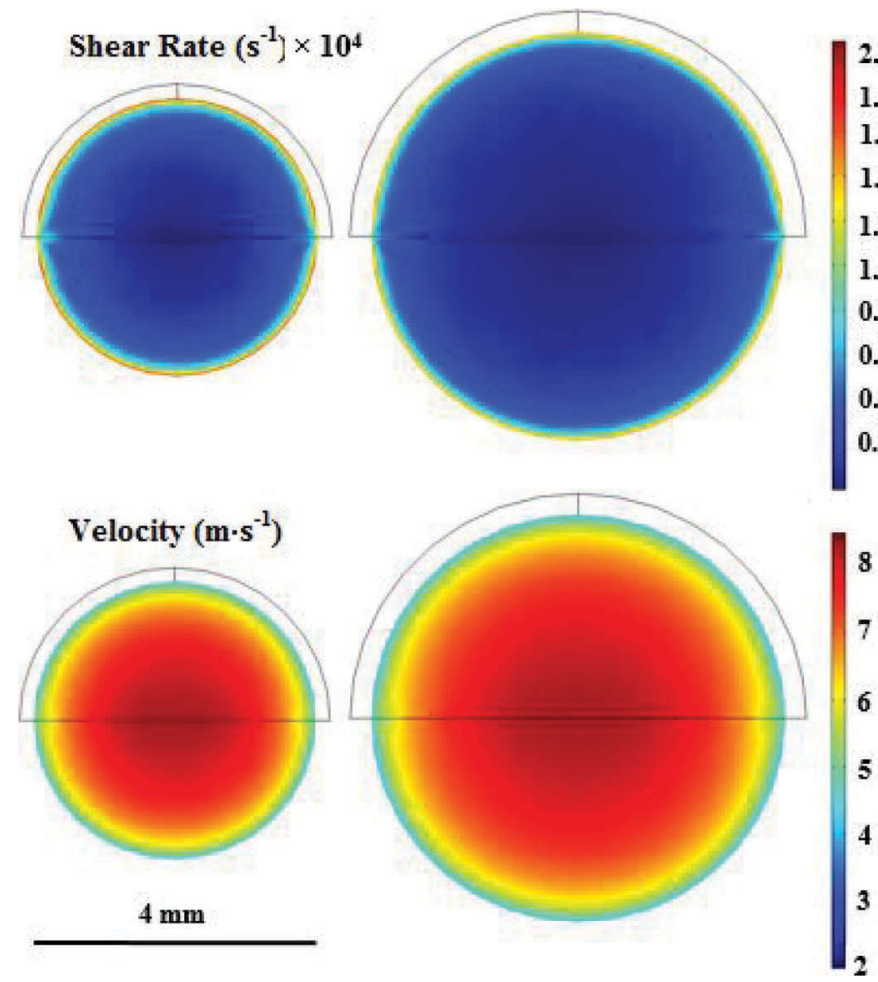

Figure 3. Radial shear rate and cross-flow velocity profiles within the $4-\mathrm{mm}$ and $6-\mathrm{mm}$ retentate flow channels during microfiltration of skim milk at $50^{\circ} \mathrm{C}$ and an average cross-flow velocity of $7 \mathrm{~m} \cdot \mathrm{s}^{-1}$. Color version available online.

the LRPC relative to that of the $4-\mathrm{mm}$ system. This was not observed, as both systems exhibited an LRPC of $11.5 \%$ (Figure 4 ). The inability to explain differences in LF in ceramic MF of skim milk and milk protein concentrate based on Re has been discussed (GesanGuiziou et al., 1999; Hurt et al., 2015). Considering the similarities between the computational fluid dynamics data in the present study (Figure 3), the inability of Re to explain differences in LRPC is not surprising. Adams et al. (2015b) determined that ceramic membranes with diamond-shaped retentate flow channels had a lower limiting flux than ceramic membranes with round retentate flow channels when cross-flow velocity and retentate protein concentration were held constant during skim milk MF. The same computational fluid dynamics technique used in the present study was used to determine that the diamond-shaped channel membranes showed regions of lower shear rates and crossflow velocities at the vertices compared with the shear rates and cross-flow velocities near the surface of the round channel membranes (Adams et al., 2015b). The present study's findings regarding LRPC are in line with those of Hurt et al. (2015) and Gesan-Guiziou et al. (1999) regarding LF: shear rate and shear stress at the membrane surface caused by changes in cross-flow dictate fouling, not Re.

When microfiltering milk protein concentrate using ceramic membranes, Hurt et al. (2015) determined that the value of a sustainable flux was about $85 \%$ of the LF, regardless of retentate protein concentration or membrane channel diameter. If the sustainable retentate protein concentration were $85 \%$ of the LRPC (11.5\%), the sustainable retentate protein concentration would be $9.78 \%$ TP. Based on Figure 4, TMP ${ }_{\text {avg }}$ increased linearly with retentate protein concentration below $9.78 \%$ and permeate TP did not decrease due to fouling (Table 4). These qualities are indicative of a sustainable MF process and suggest that multiplying the LRPC by 0.85 to derive a sustainable retentate protein concentration may be appropriate.

\section{Potential for 95\% SP Removal in 2 MF Stages}

Based on theoretical calculations described by Hurt and Barbano (2010), subjecting skim milk that is $3.20 \% \mathrm{TP}$ and $81.97 \% \mathrm{CN} \% \mathrm{TP}$ to 2 stages of MF (CF $=4.03 \times)$ with diafiltration $(4.03 \times)$ between stages, 78 and $95 \%$ of SP would be removed after the first and second stages, respectively. The calculation assumes that no SP is rejected by the membrane. A $4.03 \times$ process would produce a retentate that is $11.06 \% \mathrm{TP}$ after stage 1 and $10.62 \% \mathrm{TP}$ after stage 2 . If the sustainable retentate protein concentration was higher than $11.06 \%$, $95 \% \mathrm{SP}$ removal could be accomplished in 2 stages. The 6-mm system retentate recirculation pump frequency was $54.2 \mathrm{~Hz}$ (Table 7) when average cross-flow velocity

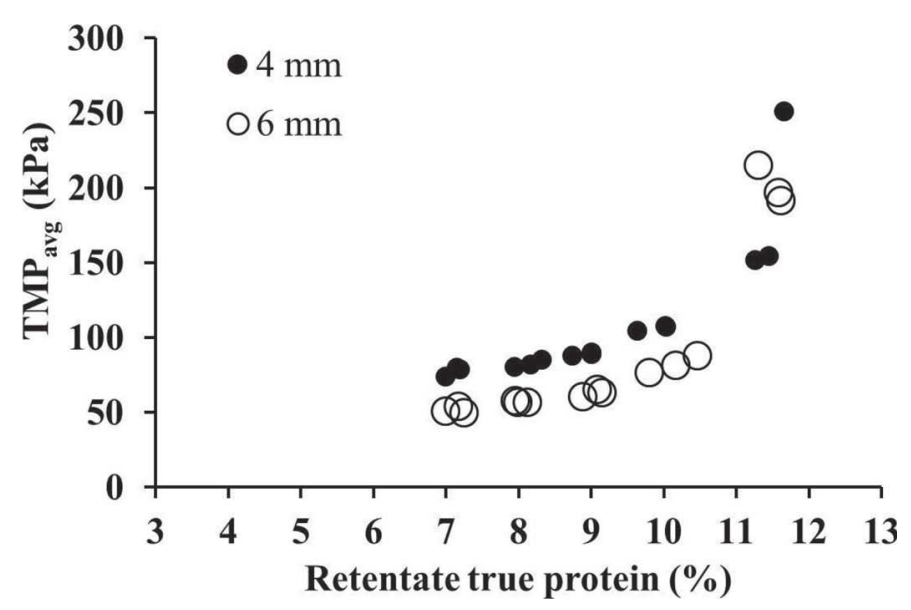

Figure 4. Average transmembrane pressure $\left(\mathrm{TMP}_{\text {avg }}\right)$ as a function of retentate true protein concentration when microfiltering skim milk using $4-\mathrm{mm}$ and $6-\mathrm{mm}$ round channel membranes. Temperature $=$ $50^{\circ} \mathrm{C}$; average cross-flow velocity $=7 \mathrm{~m} \cdot \mathrm{s}^{-1}$. Data from all 3 replicates are shown. 
was $7 \mathrm{~m} \cdot \mathrm{s}^{-1}$ at $11.5 \%$ retentate TP. By increasing the pump frequency to $70 \mathrm{~Hz}$, cross-flow velocity would be increased to approximately $9 \mathrm{~m} \cdot \mathrm{s}^{-1}$. Assuming that the $50^{\circ} \mathrm{C}$ viscosity trend in Figure 2 holds at higher protein concentrations and that LRPC scales linearly with the average cross-flow velocity, as LF have been shown to do (Samuelsson et al., 1997), the LRPC at $9 \mathrm{~m} \cdot \mathrm{s}^{-1}$ would be $13.29 \%$ (viscosity $=3.11 \mathrm{mPa} \cdot \mathrm{s}$, Figure 2). Multiplying $13.29 \%$ by 0.85 yields a sustainable retentate protein concentration of $11.30 \%$. Given that the $6-\mathrm{mm}$ system can achieve a higher cross-flow velocity than the $4-\mathrm{mm}$ system at a given pump frequency, $95 \% \mathrm{SP}$ removal could likely be accomplished in 2 stages using the $6-\mathrm{mm}$ membranes if the average cross-flow velocity were increased to $9 \mathrm{~m} \cdot \mathrm{s}^{-1}$ and flux were maintained at $55 \mathrm{~kg} \cdot \mathrm{m}^{-2} \cdot \mathrm{h}^{-1}$. Reducing the number of stages from 3 , as proposed by Hurt and Barbano (2010), to 2 to accomplish $95 \%$ SP removal would reduce the number of pumps and recirculation loops in the MF system. This could potentially reduce the fixed costs of a $95 \% \mathrm{SP}$ removal process.

\section{Process Monitoring}

The retentate protein concentration must be monitored to maintain a sustainable MF operation in which fouling is low. We monitored our MF system by measuring the retentate TP concentrations by MIR. However, MIR technology may not be available to every MF operator. If viscosity data or processing data based on the retentate recirculation pump (i.e., pump frequency) were available, these could also be used to monitor a system's retentate TP concentration, assuming temperature and cross-flow velocity were held constant. Figure 5 shows linear correlations among retentate TP measured by MIR, retentate TP measured by Kjeldahl, retentate viscosity at $50^{\circ} \mathrm{C}$, and the retentate recirculation pump frequency necessary to maintain a cross-flow velocity of $7 \mathrm{~m} \cdot \mathrm{s}^{-1}$ at $50^{\circ} \mathrm{C}$. Correlations among viscosity and retentate protein by either method of determination did not depend on the membrane system used, but the retentate recirculation pump frequency was membrane-dependent. The excellent correlations $\left(\mathrm{R}^{2}>\right.$ 0.98) among all 4 factors demonstrate their usefulness as monitoring tools in a MF process. Consequently, a MF processor wishing to monitor its retentate protein concentration could correlate protein data to another measurement using a more readily available device such as a rotational viscometer or flow meter that is already installed in the process. At a constant temperature, as protein concentration increases, viscosity and the pump frequency required to maintain a given cross-flow velocity will increase.

\section{Retentate Recirculation Pump Energy}

Polymeric spiral-wound membranes are the most widely used membrane geometry in the dairy industry today. They cannot be subjected to high cross-flow velocities (i.e., $>1 \mathrm{~m} \cdot \mathrm{s}^{-1}$ ) because the spiral-layered structure of the membranes would separate under the high shear stresses. Because increasing the cross-flow velocity increases the LF, tubular ceramic MF systems can be operated at higher fluxes than spiral-wound polymeric membranes (Zulewska et al., 2009). However, ceramic MF systems require more energy to operate than spiral-wound polymeric MF systems (Cheryan, 1998). The difference in energy use is almost entirely due to the cross-flow velocity provided by the retentate recirculation pump in a ceramic MF process. If energy consumption could be reduced while maintaining crossflow, variable costs would decrease and may make ceramic systems more cost efficient.

The energy required to operate the retentate recirculation pump for each membrane module in the present study at a retentate protein concentration of $9 \%$, a flux of $55 \mathrm{~kg} \cdot \mathrm{m}^{-2} \cdot \mathrm{h}^{-1}$, and an average cross-flow velocity of 7 $\mathrm{m} \cdot \mathrm{s}^{-1}$ was calculated on a per unit volume of permeate basis according to Equation [3]. Although the 6-mm system required a higher retentate recirculation rate (Q) to reach the same cross-flow velocity (Table 7) and had a lower modular membrane surface area than the 4-mm membrane $\left(1.08 \mathrm{~m}^{2}\right.$ vs. $\left.1.41 \mathrm{~m}^{2}\right)$, the 4 -mm system required $21 \%$ more energy ( 33.32 vs. $27.47 \mathrm{~kW} \cdot \mathrm{h} \cdot \mathrm{m}^{-3}$ ) to produce the same amount of permeate as the $6-\mathrm{mm}$ system. The difference in energy consumption can be attributed the higher $\Delta \mathrm{P}$ associated with the 4-mm system (Table 6). Energy consumption for both systems would increase if the flux were decreased or if the retentate protein concentration were increased. This indicates that although the LRPC for the 2 systems may not have been different, there may be a cost advantage to using the 6-mm membranes if a processor wanted to produce a retentate with a higher protein concentration. To increase the retentate protein concentration at the same flux would require a higher cross-flow velocity. The larger channel diameter of the 6 -mm system would allow this velocity to be reached at a lower $\Delta \mathrm{P}$. This finding becomes important when limitations on the size of the retentate recirculation pump come into consideration (i.e., the maximum pump pressure output or pump frequency is approached).

\section{CONCLUSIONS}

When temperature, flux, and average cross-flow velocity were controlled, retentate flow channel diameter 
did not affect the LRPC of nongraded permeability ceramic membranes operated in nonuniform transmembrane pressure mode. This indicates that the LRPC is not a function of Re. Computational fluid dynamics data, which indicated that both membranes had similar radial velocity profiles within their retentate flow channels, supported this finding. Membranes with 6-mm flow channels can be operated at a lower $\Delta \mathrm{P}$ or at a higher cross-flow velocity, depending on which is controlled, than membranes with 4-mm flow channels with the same pore size. This implies that 6 -mm membranes could achieve a higher LRPC than 4-mm membranes at the same $\Delta \mathrm{P}$ due to an increase in cross-flow velocity. In theory, the higher LRPC of the 6-mm membranes could facilitate $95 \% \mathrm{SP}$ removal in $2 \mathrm{MF}$ stages with diafiltration between stages if no SP were rejected by the membrane. This may reduce the fixed costs of an MF system needed to achieve $95 \%$ SP reduction. At the same flux, retentate protein concentration, and average cross-flow velocity, 4 -mm membranes require $21 \%$ more energy to remove a given amount of permeate than 6-mm membranes, despite the lower surface area of the 6-mm membranes. Equations to predict skim milk MF retentate viscosity as a function of protein concentration and temperature were provided. Retentate viscosity, retentate recirculation pump frequency required to maintain a given cross-flow velocity at a given retentate viscosity, and retentate protein determination by MIR were all useful tools for monitoring the retentate protein concentration to ensure a sustainable MF process.

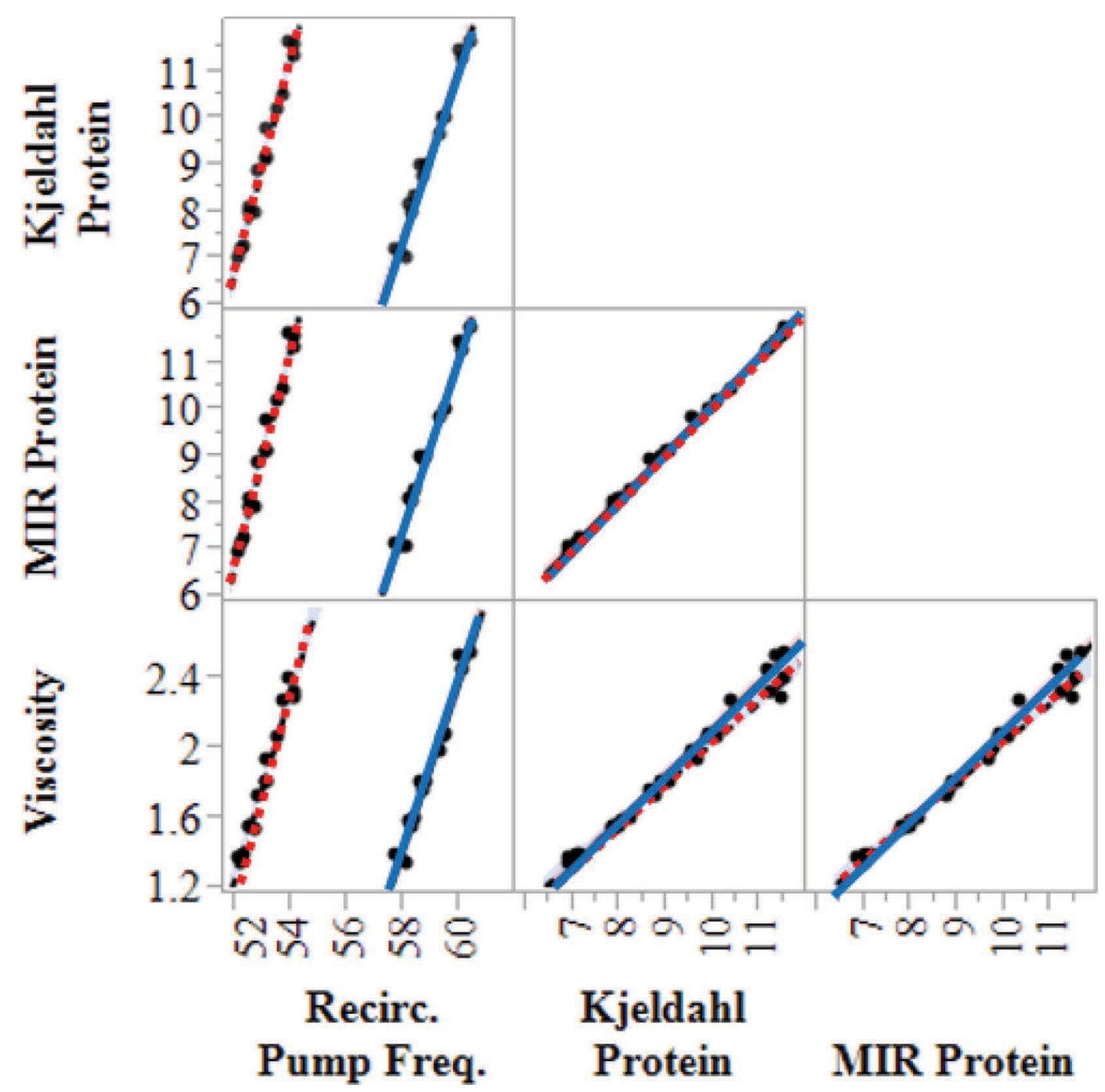

Figure 5. Scatterplot matrix of retentate true protein (\%) as determined by Kjeldahl or a mid-infrared (MIR) spectrophotometer, retentate apparent viscosity $\left(\mathrm{mPa} \cdot \mathrm{s}\right.$, temperature $=50^{\circ} \mathrm{C}$, shear rate $\left.=73 \mathrm{~s}^{-1}\right)$, and retentate recirculation pump frequency $(\mathrm{Hz})$ required to maintain an average cross-flow velocity of $7 \mathrm{~m} \cdot \mathrm{s}^{-1}$ during microfiltration at $50^{\circ} \mathrm{C}$ using either $4-\mathrm{mm}$ (solid/blue line) or 6-mm (dotted/red line) round channel membranes. $\mathrm{R}^{2}$ for all correlations $>0.98$. Data from all 3 replicates are shown. Color version available online. 
Using 6-mm membranes instead of 4-mm membranes would be advantageous for processors wishing to reduce energy costs or maximize the protein concentration of an MF retentate.

\section{ACKNOWLEDGMENTS}

The authors thank the New York State Milk Promotion Board (Albany, NY) and Northeast Dairy Foods Research Center (Ithaca, NY) for partial funding of this research. The technical assistance of Michelle Bilotta, Sara Bova, Chassidy Coon, and Larissa Viera di Marzo from the Department of Food Science at Cornell University was greatly appreciated. The authors also thank Alexander Warning from the Department of Biological and Environmental Engineering at Cornell University for his help in developing the COMSOL models.

\section{REFERENCES}

Adams, M. C., E. E. Hurt, and D. M. Barbano. 2015a. Impact of soluble calcium and lactose on limiting flux and serum protein removal during skim milk microfiltration. J. Dairy Sci. 98:74837497. http://dx.doi.org/10.3168/jds.2015-9474.

Adams, M. C., E. E. Hurt, and D. M. Barbano. 2015b. Effect of ceramic membrane channel geometry and uniform transmembrane pressure on limiting flux and serum protein removal during skim milk microfiltration. J. Dairy Sci. 98:7527-7543. http://dx.doi. org/10.3168/jds.2015-9753.

Amelia, I., and D. M. Barbano. 2013. Production of an $18 \%$ protein liquid micellar casein concentrate with a long refrigerated shelf life. J. Dairy Sci. 96:3340-3349.

Anema, S. G. 2009. Effects of milk solids concentration on the $\mathrm{pH}$ soluble calcium, and soluble phosphate levels of milk during heating. Dairy Sci. Technol. 89:501-510.

AOAC International. 2000. Official Methods of Analysis. 17th ed. AOAC International, Gaithersburg, MD.

Bacchin, P., P. Aimar, and R. W. Field. 2006. Critical and sustainable fluxes: Theory, experiments, and applications. J. Membr. Sci. 281:42-69.

Beckman, S. L., and D. M. Barbano. 2013. Effect of microfiltration concentration factor on serum protein removal from skim milk using spiral-wound polymeric membranes. J. Dairy Sci. 96:61996212 .

Belfort, G., R. H. Davis, and A. L. Zydney. 1994. The behavior of suspensions and macromolecular solutions in crossflow microfiltration. J. Membr. Sci. 96:1-58.

Brookfield Engineering Laboratories Inc. 2014. More solutions to sticky problems. Accessed Apr. 20, 2015. http://www. brookfieldengineering.com/download/files/more_solutions.pdf.
Cheryan, M. 1998. Ultrafiltration and microfiltration handbook. Page 339 in Costs and Processing Economics. Technomic Publishing Company Inc., Lancaster, PA.

COMSOL. 2013. Which turbulence model should I choose for my CFD application? Accessed Mar. 13, 2015. http://www.comsol.com/ blogs/which-turbulence-model-should-choose-cfd-application/.

Fernandez-Martin, F. 1972. Influence of temperature and composition on some physical properties of milk and milk concentrates II: viscosity. J. Dairy Res. 39:75-82.

Gesan-Guiziou, G., G. Daufin, E. Boyaval, and O. Le Berre. 1999. Wall shear stress: effective parameter for the characterization of the cross-flow transport in turbulent regime during skimmed milk microfiltration. Lait 79:347-354.

Glantz, S. A., and B. K. Slinker. 2001. Multicollinearity and what to do about it. Pages 185-187 in Primer of Applied Regression and Analysis of Variance. 2nd ed. McGraw-Hill Inc. New York, NY.

Hurt, E., and D. M. Barbano. 2010. Processing factors that influence casein and serum protein separation by microfiltration. J. Dairy Sci. 93:4928-4941.

Hurt, E., J. Zulewska, M. Newbold, and D. M. Barbano. 2010. Micellar casein concentrate production with a $3 \mathrm{X}, 3$-stage uniform transmembrane pressure ceramic membrane process at $50^{\circ} \mathrm{C}$. J. Dairy Sci. 93:5588-5600.

Hurt, E. E., M. C. Adams, and D. M. Barbano. 2015. Microfiltration: Effect of channel diameter on limiting flux and serum protein removal. J. Dairy Sci. 98:3599-3612.

Kaylegian, K. E., G. E. Houghton, J. M. Lynch, J. R. Fleming, and D. M. Barbano. 2006. Calibration of infrared milk analyzers: Modified milk versus producer milk. J. Dairy Sci. 89:2817-2832.

Mulder, M. 1994. Membranes processes in separation and purification. Page 459 in Energy Requirements in Membrane Separation Processes. Kluwer Academic Publishers, Dordrecht, the Netherlands.

Samuelsson, G., I. H. Huisman, G. Tragardh, and M. Paulsson. 1997. Predicting limiting flux of skim milk in crossflow microfiltration. J. Membr. Sci. 129:277-281.

Sauer, A., I. Doehner, and C. I. Moraru. 2012. Steady shear rheological properties of micellar casein concentrates obtained by membrane filtration as a function of shear rate, concentration, and temperature. J. Dairy Sci. 95:5569-5579.

Solanki, G., and S. S. H. Rizvi. 2001. Physico-chemical properties of skim milk retentates from microfiltration. J. Dairy Sci. 84:23812391

USDA. 1965. Pages 1-74 in Full committee report of study conducted in thirteen federal milk order markets on volume-weight conversion factors for milk. Supplement to marketing research report 701 . Consumer and Marketing Service, Dairy Division, USDA, Washington, DC.

Wojciechowski, K. L., and D. M. Barbano. 2015. Modification of the Kjeldahl noncasein nitrogen method for bovine milk concentrates and milks from other species. J. Dairy Sci. 98:7510-7526.

Zulewska, J., M. Newbold, and D. M. Barbano. 2009. Efficiency of serum protein removal from skim milk with ceramic and polymeric membranes at $50^{\circ}$ C. J. Dairy Sci. 92:1361-1377. 